\title{
European Identity and Redistributive Preferences
}

\section{Joan Costa-Font \& Frank Cowell}

Working paper 3

December 2015 


\section{LSE International Inequalities Institute}

The International Inequalities Institute (III) based at the London School of Economics and Political Science (LSE) aims to be the world's leading centre for interdisciplinary research on inequalities and create real impact through policy solutions that tackle the issue. The Institute provides a genuinely interdisciplinary forum unlike any other, bringing together expertise from across the School and drawing on the thinking of experts from every continent across the globe to produce high quality research and innovation in the field of inequalities.

Our working papers series publications are available to download free from our website: www.lse.ac.uk/lllpapers.

For further information on the work of the Institute, please contact the Institute Manager, Liza Ryan at e.ryan@Ise.ac.uk.

International Inequalities Institute

The London School of Economics and Political Science

Houghton Street

London

WC2A 2AE

Email: Inequalities.institute@Ise.ac.uk

Web site: www.Ise.ac.uk/III

@LSEInequalities

(C) F. Cowell and J. Costa-Font. All rights reserved.

Short sections of text, not to exceed two paragraphs, may be quoted without explicit permission provided that full credit, including $\odot$ notice, is given to the source. 


\title{
Editorial note and acknowledgements
}

We are very grateful to Ilia Karmanov and Julia Philipp for excellent research assistance and to STICERD for funding support.

\begin{abstract}
How important is spatial identity in shifting preferences for redistribution? This paper takes advantage of within-country variability in the adoption of a single currency as an instrument to examine the impact of the rescaling of spatial identity in Europe. We draw upon data from the last three decades of waves of the European Values Survey and we examine the impact of joining the single currency on preferences for redistribution. Our instrumentation strategy relies on using the exogenous effect of joining a common currency, alongside a battery of robustness checks and alternative instruments. Our findings suggest that joining the euro has a boosting effect on European identity; an opposite and comparable effect is found for national pride. We find that European identity increases preferences for redistribution, and that national pride exerts an equivalent reduction in preferences for redistribution.
\end{abstract}

Keywords: spatial identity, Europe, welfare state support

JEL Code: D69, O52, H53 


\section{Contents}

1. Introduction .5

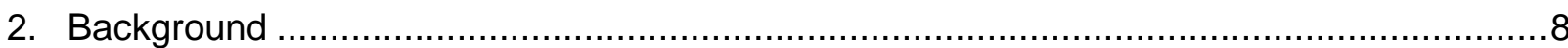

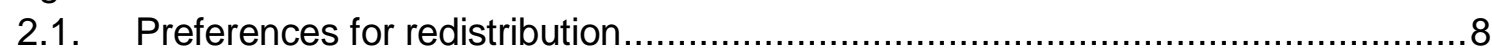

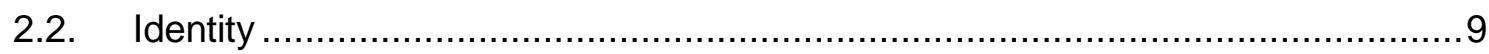

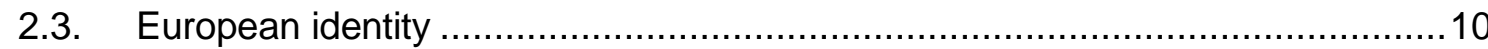

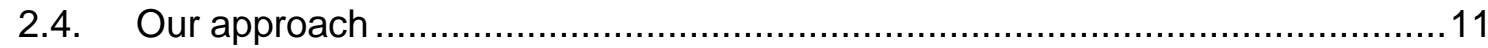

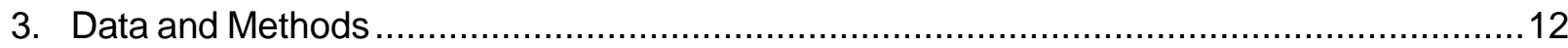

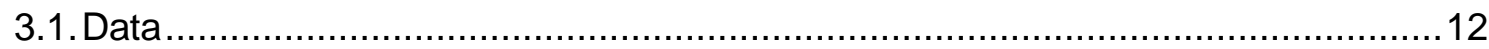

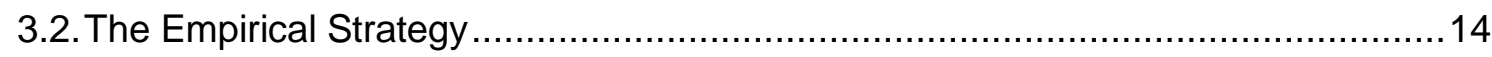

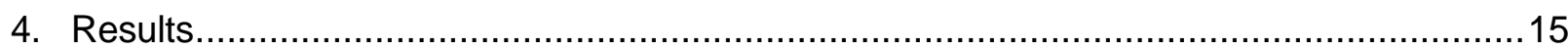

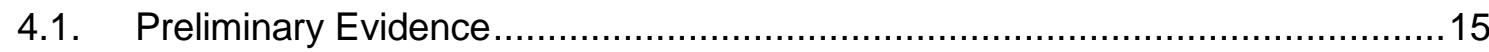

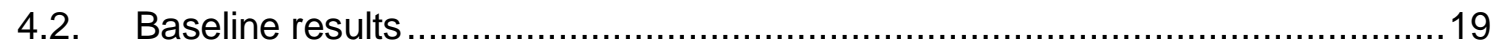

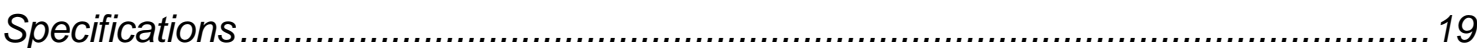

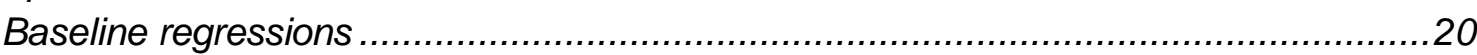

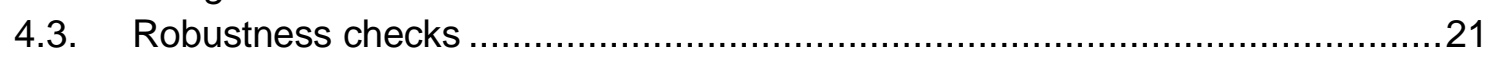

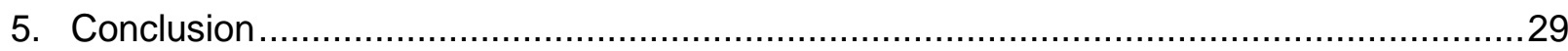

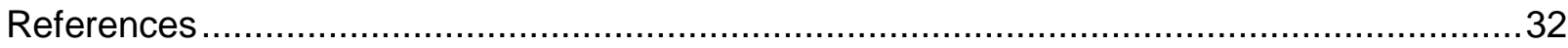

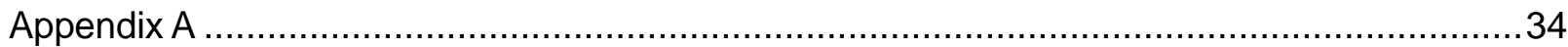

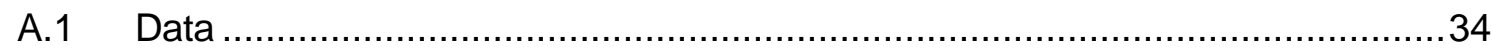

A 1.1 Summary characteristics.................................... 33

A 1.2 Background information: Citizenship education..............................34

A 1.3 Background information: Foreign language proficiency .....................35

A 1.4 Background information: Medals in Olympic Games .........................37

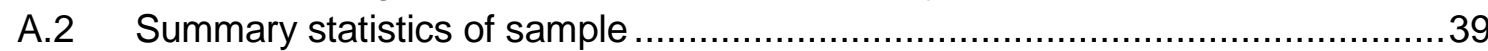

A 3 Trends in preference and identity variables................................ 41

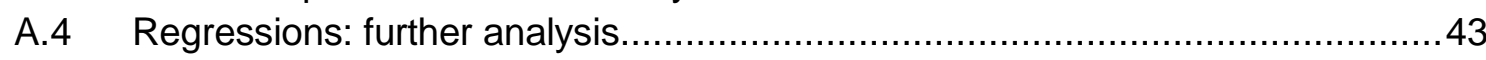




\section{Introduction}

We still know relatively little about what shapes preferences for redistribution. The standard political economy theory of redistribution (Meltzer and Richard 1981, Romer 1975), linking the expansion of gross income inequality to increased demands for redistribution, has not been consistently validated in practice (Georgiadis and Manning 2012, Gouveia and Masia 1998). Other explanations focus on the presence of biased perceptions of redistribution, ${ }^{1}$ the expectations of offspring social mobility (Banabou and Ok 2001), the influence of ethnic fractionalisation (Alesina et al. 2001) or the role of genetics. $^{2}$

Here we focus on the influence of social identity on preferences for redistribution, that is, the presence of common reference points (prescriptions) acting as social norms (Akerlof and Kranton 2000) which influence behaviour within the social group; the identity mechanism then confers some sense of social solidarity on the members of the group. If identity plays this role and solidarity is determined within the context of the nation, a move from that setting to another will affect people's preferences for redistribution. However, it may be that the development of a European identity affects the extent of solidarity and individual experiences within a wider community. The move from the default of national solidarity expression may be pro-redistributive.

Identity might contribute to the development of cognitive biases insofar as a person's reference group is not the whole population but that of his group, or his country. People in relatively rich countries may perceive themselves as being poorer than they really are, not so much because of an information bias, but because their reference point is based on the social group they identify with, and not necessarily the whole population. So an important question for empirical purposes is that of identifying whether an exogenous change in reference point, such as the relevant spatial dimension of identity (Europe $\mathrm{v}$ national), exerts an influence on distributional preferences. Ignoring identity and relying on an individualistic model of self-interested demand for redistribution will underestimate the benefits of redistribution itself. ${ }^{3}$ Processes of regional integration offer a unique natural experiment to examine such a question in the field.

Social identities shape individuals' preferences by defining a "sense of belonging" to a club good that appears in people's utility functions (Akerlof 1997). Accordingly, an individual suffers disutility from deviating from his or her category norms, which induces behavior and influences preferences has wide- ranging implications for welfare economics ${ }^{4}$

\footnotetext{
1 It is common to find some disconnect between how preferences are perceived and true distribution of wealth and income. Norton and Ariely (2011) find that perceptions of wealth distribution do not correspond to real wealth distribution in the US. Reducing the information bias that individuals have with regards to their position in the income distribution influences redistributive preferences (Cruces et al. 2013). 2 Zakharov and Ponarin (2013) examined data from redistribution in Russian regions and find that individuals with similar genetic makeup ( $\mathrm{L}$ allele) systematically prefer more redistribution.

3 Carlsson et al. (2014) find that pro-social preferences are stable over time in an experimental setting.

4 Social identity has been suggested to reduce altruism and redistribution (Luttmer 2001, Shayo 2009 , Costa-Font and Cowell 2015).
} 
that conforms to those norms (Akerlof and Kranton 2000). The extent to which identity is feeling part of a group triggers more positive social evaluation towards the group (Cremer and Vugt 1999, Gaertner et al. 1989). The substitution of a national currency by a common currency (the euro) may have triggered some salience to the European project resulting in a greater weight of the European component of people's identity; at the same time identity may remain highly valued as a position good, especially for European countries that did not enjoy the club status with their own national attachments. Identification with a polity largely depends on the status of the groups compared to the alternative possible status (Roccas 2003).

Our focus in this paper is on individuals' redistributive preferences, and we claim that the development of a European identity resulting from institutional reforms such as the introduction of a common currency provides quasi- experimental evidence to examine it. Europe is the ideal setting to study changes in identity, given that the progressive integration process exerts effects on welfare-state institutions, which in turn can influence the existing welfare institutions by affecting people's redistributive preferences. The unique experience of the setting up of a single currency exerted a non-neutral effect on European attachment as measured by confidence in the EU, and reduced national pride. This result is consistent with other findings that indicate that European identity explains satisfaction with democracy (Hobolt 2012). Similarly, Risse (2010) finds that people who identify themselves as European are more likely to identify with the values of tolerance and democracy.

The intuition behind the paper is that, when identity is defined by a "broader other," people are more likely to express a preference for true redistribution (redistribution in small communities might be partially explained by exchange motivations instead). Becoming part of the Eurozone club in a setting where redistribution is primarily undertaken by national welfare states should not change the individual's expectation of benefiting from redistribution, and should primarily affect the rescaling of people's spatial identity. However, there is a potential reverse causality that should be taken into account: a revival of anti- European nationalism (which we proxy here by national pride) is underpinned by anti-immigration attitudes; also there might be a problem with omitted- variable bias if some confounding variables correlated with identity. In this paper we propose an instrumental-variable strategy that takes advantage of the adoption of a common currency (a largely exogenous decision to individuals themselves). We focus on countries that adopted the common currency only after its inception so that we can observe a period before and after being part of the common 
currency. We use other instruments to measure the robustness of our results. Finally, we use different subsamples to ascertain whether the results hold beyond the specific country sample.

Our paper brings together different strands of the literature. We incorporate some findings from the European politics literature suggesting that some aspects of national identity are substituted for, with the expansion of European identity. This not only changes people's affiliations but also preferences towards equality. In a more competitive setting, such as that of a wider European Union, wide inequalities are likely to emerge and so the role of redistributive mechanisms becomes more important. We contribute to the literature on preference for redistribution and the limitations of the Meltzer and Richard approach. Third the paper contributes to the role of identity in influencing economic behaviour (Akerlof and Kranton 2000, 2005). If changes in institutions affect people's preferences by changing their identification and collective affiliations then policy needs to be focused more strongly on such indirect effects. Finally, this paper extends the findings of Luttmer (2001), suggesting that preferences for redistribution change with the share of the poor in a region, as Eurozone enlargement to central and Eastern Europe might have exerted an impact on preferences for redistribution. However, we argue that the mechanism for such an effect is channeled through identity.

Section 2 provides the background to the analysis of this paper. Section 3 describes the data and methods, section 4 presents results and the paper concludes with section 5 . 


\section{Background}

There are two important branches of the economics literature that connect to the approach that we use in this paper: the literature on redistributive preferences and the literature on the economics of identity.

\subsection{Preferences for redistribution}

Economic approaches to redistribution such as Meltzer and Richard (1981) typically assume that people's position in society determines their preferences ${ }^{5}$ and often disregard how people's social groupings influence preferences. But groupings are important: for example, ethnically diverse societies exhibit less class conflict or, if they do, it is more rare as ethnicity or identity add additional dimension to the political spectrum away from purely economic or redistributive questions (Lee and Roemer 2006).

In the last twenty years we have seen an increasing interest in examining how multiculturalism and diversity influence preferences for redistribution. Alesina et al. (2001) find that ethnic fractionalisation exerts an influence on redistributive preferences in the context of the United States where the default is not a consolidated welfare state as in Europe. Luttmer (2001) finds a negative relationship between diversity and preferences for redistribution: people's preferences for redistribution are interdependent in the sense that preference is influenced by the characteristics of other individuals around them. People appear to be more likely to redistribute to the groups they identify with, be that identification based on ethnicity, religious group, social class, region or something else.

Preferences for redistribution have been found to be related to voting behaviour and political ideology, ${ }^{6}$ to people's own self-interest, 7 to their evaluation of inequalities, ${ }^{8}$ and to their perceptions of the "leaky bucket", the efficiency of the transfer mechanism (Krawczyk 2010).

Furthermore, redistributive preferences may reflect cultural differences (Luttmer and Singhal 2011) and political differences. ${ }^{9}$ But these differences are not exogenous or immutable and may be associated with the phenomenon of identity.

\footnotetext{
5 By "preferences for redistribution" we mean the generalized support for the transfer of resources to ex-ante undetermined individuals by a set of mechanisms that include taxation, welfare policies and other.

6 Giuliano and Spilimbergo (2014) find evidence that experiencing a recession during early adulthood affects preferences for redistribution.

7 Durante et al. (2014) conducted a laboratory study to test for the role of redistribution, risk aversion and social preferences as drivers of preferences for redistribution, finding evidence of all of them but with a stronger effect for self-inter
} 


\subsection{Identity}

"Identity" refers to mechanisms through which individuals become attached to each other by creating a sense of belonging (Tajfel 1978). Akerlof and Kranton (2000) consider identity as an externality on people's actions triggered by the presence of common social norms: these are common reference points that can shift over time. Collective identities are the expressions of different cultures which can be an important source of preference endogeneity (Bowles 1998) and a recent survey suggests that they can explain individuals' solidarity attitudes (Costa-Font and Cowell 2015). People may alter their behaviour to conform to other people's expectations and social norms (Asch 1951) beyond their narrow personal self-interest. ${ }^{10}$

Social identity can have inward effects on the person, and an outward effect on the group (Mayer and Palmowski 2004). Clearly a person may be associated with multiple groups and, as a result, reveal multiple identities - for example regional and European identities. Some identities attributed to a person may conflict with each other and even become "oppositional" (Battu and Zenou 2010), but others may not. Identities have been seen as a multidimensional social categorization that can be primed by certain circumstances or events. Easton (1975) distinguishes instrumental and affective support for political institutions. If an institution is perceived as being instrumentally beneficial, the attachment to that institution would be expected to increase. Inglehart and Raabier (1978) have put forward the theory of cognitive mobilization whereby education exerts an effect on individuals' cosmopolitan identity.

Consider the connection with redistributive preferences discussed in section 2.1. National or social identity can act as a "social tie," which in turn operates in enhancing support for the welfare state (Costa-Font and Cowell 2015). ${ }^{11}$ Redistribution is one of the central features of welfare states: maintenance of redistributive institutions largely depends on individual support for taxing higher incomes more heavily and targeting expenditures to social need. Since such activities are typically associated with nations, the question arises whether support for redistributive institutions and programs varies with the rescaling of individuals' identities to both supranational and subnational bodies.

8 Fong and Luttmer (2011) find that the source of inequality matters.

${ }^{9}$ For example, countries under socialism exhibited higher redistributive preferences (Corneo and Gruner 2002).

10 Klor and Shayo (2010) find experimental evidence that when individual sacrifice was not too high, they accommodate their preferences to those of the group. Charness (2007)0 and Chen and Li (2009) show that individuals are altruistic towards the people that belong to the group they identify themselves with. Lindqvist and Ostling (2013) find that in low tax countries some share of the poor identify with their ethnicity and favour low taxes; ethnically homogenous societies exhibit more redistribution

11 However, the underpinning mechanisms for the tying effect are still not well known. For instance, some research in political science argues that the strengthening support of Canadian national identity lies in the effect the welfare state has had in building national identity, and not the other way round (Johnston et al. 2010). 
Clearly this is of particular interest with reference to a supranational organisation such as the European Union.

\subsection{European identity}

In principle European identity could play a role similar to that of American identity, uniting people by transcending borders, and especially racial divisions (Transue 2007). A superordinate identity eliminates the effects of parochialism, country nationalism and group identity. The "European project" certainly raises interesting questions in connection with the mechanisms of redistribution and perceptions of identity. With European integration, the efficient level of redistribution scales up to the European rather than the country level (Cassela and Fray 1992) and is likely to change the strength of people's attachments to state sovereignty as the institutions in member countries become locked into this emerging structure (Eichengreen 2008).

The rise of a European common identity acts on people's attitudes as a proredistributive force that confronts the existence of own-nationality bias (Lowes et al. 2015). This is, perhaps, to be expected as spatial identities are potentially rescaled from solely national to the supranational, European, level. However, within this structure there is a variety of identities - national, regional, European - and we know little about the relations between these identities, whether they are complementary, substitute or independent. So it is not clear a priori whether the priming of an identity (as mentioned in section 2.2) would exert an external effect on others.

However, among the variety of priming events that might be considered relevant, one of the most important would be the setting up of a common currency. The introduction of a single currency encompasses the reduction of one of the most important old symbols of national identity; so one should expect it to exert an influence on people's identification: the euro exemplifies the strategy of burning one's boats. For many countries joining the euro club has meant a way to improving their status worldwide, and hence it implied positive social externality. Support for the euro has remained stable, even through the recent crisis; ${ }^{12}$ but whether such (largely exogenous) externality leads to stronger preference for redistribution is an empirical question. 


\subsection{Our approach}

In this paper we take advantage of an institutional reform, the adoption of the single currency, which we argue has had a symbolic effect on priming European identity. The introduction of the euro and its effects when the national currencies were effectively replaced would be expected to have had an effect on attitudes and preferences. We can test whether that effect was stronger for countries that joined the euro initially than for the rest.

But capturing identity empirically is not a simple task. Most studies rely on survey questions which identify some component of a "latent European identity." Some evidence finds that the stronger is the feeling of national identity, the weaker is support for the European Union (Carey 2002). So here we use both national pride and confidence in the European Union to proxy the underlying European identity. Our identification strategy hinges on taking advantage of cross-country variation in preferences and collective identification (social identity) over time. A key challenge is to control for potential omitted variables. Indeed, cohort effects are important because individuals of the same cohort share similar experiences and observable similar constraints.

Given that our results are affected by a number of potential individual characteristics, we look at the presence of heterogeneous effects and subsample analysis and robustness checks such as examining the role of additional instruments (such as years of citizenship education to instrument European Union confidence and medals in the Olympic games to instrument national pride, as well as peer effects).

\footnotetext{
12 This is in contrast to trust in European institutions generally, which has fallen. Guiso et al. (2014) find that the main determinants of positive sentiment towards the EU is the quality of government, and develop an argument on institutional arbitrage: the change in support to EU integration is determined by a change in support for the single market and the change in support for a single currency. Positive sentiments towards the EU are primarily affected negatively by unemployment and the enlargement post 2004 in Southern European countries. Education, age, gender, and the socio-economic status of individuals have consistently been found to be salient contributors to individuals' support for the EU. Age, income, occupation, and political values are not merely controls in this analysis but rather contribute to individuals' cognitive development and thus understanding of the EU project (Inglehart 1991).
} 


\section{Data and Methods}

\subsection{Data}

Our primary dataset on preference for redistribution and identity is the European sample of the World Values Survey, also known as European Values Survey for the period 1981-2014. The dataset provides with a series of repeated cross sections observations on the ideas, beliefs, preferences, attitudes, values and opinions of citizens all over Europe. We have employed records of individual specific redistributive preferences, alongside rich measures of spatial or geographic identity that are recorded in the European Values Survey. Specifically, we use self-reported measures of individual's preference for redistribution, which have been validated in previous studies. ${ }^{13}$

We focus on a set of countries that joined the European Union after 2004. Not all countries are covered in each survey wave, but the years range from 1981 to 2014 (for details see the summary statistics in the Appendix). Overall we are left with a fairly large sample of 27,376 respondents. There are several advantages of using such a sample. First, it allows one to identify the effect of joining the common currency (adopting the euro), in contrast to using the total sample of European Union countries; the founding countries of the euro substituted the currency almost at the same time and hence there is not enough variability to exploit.14 The second advantage of using a sample of those that joined the euro after 2004 is that there is likely to be an attraction for joining the euro club ("institutional arbitrage" in the spirit of Guiso et al. 2014) which plays out in terms of boosting European identity and hence "widening the spatial identity beyond the national reach." Finally the introduction of the common currency was an unexpected effect within the time frame of the survey questions (4-6 years), and so it is unlikely that anticipation effects (on the final success of an economy in joining a common currency) could threaten the identification of the effect on spatial identity.

\footnotetext{
13 Giuliano and Spilimbergo (2014) show that redistributive preferences correlate in the expected way with political leanings.

${ }^{14}$ In addition, exchange rates were pegged from 1999 and hence, the effect of the common currency was already expected and discounted for in such a broader sample.
} 


\section{EVS: Key Questions}
A. Redistributive Preferences
Rate your agreement on this scale:
1. "Incomes should be made more equal"
10. "We need larger income differences as incentives for effort"

B. National Pride

How proud are you to be X?

[Very proud, Quite Proud, Not very Proud, Not at all Proud]

C. Confidence in the EU

I am going to name a number of EU organisations...

...how much confidence [do] you have in them?

[Great deal of confidence, quite a lot of confidence,

...not very much confidence, none at all]

As noted, the redistributive preference question is extensively used in the literature, and refers to a general question about redistribution without specifying the level of authority responsible to make incomes more equal. This way, it can be argued to be institutionally neutral. By contrast, national pride relates to restricted loyalties to national groups which depend on the perceptions of status of national communities. Hence, in this paper we hypothesize that becoming fully part of a larger community (for example by joining the euro area) would be expected to weaken the effect of national pride. Finally, we use confidence in the European Union. This is a different question from trust in the working of European institutions: it captures in a multi-question format the perceptions of individuals in post-2004 European countries of their degree of attachment to the European Union. This question has been found to correlate well with other attitudes towards Europe in the sample.

Tables A.1 and A.2 in the Appendix show the samples and countries included in the dataset alongside the main sample characteristics such as the average age, the percentage of women, education attainment, family characteristics and size and political affiliation. The sample size of each country is about 1000 respondents. Table A.3 displays the sample size of the survey waves which is larger for 1991- 98 than the rest. Tables A.4 to A.6 show the distribution of the main study variables and Table A.7 the proportion of countries that have adopted the euro in the total sample (13\%). 


\subsection{The Empirical Strategy}

Our identification strategy relies on selecting a sample of countries that have progressively joined the European Union for which we can identify a period before and a period after they adopt the euro as a currency. In doing so, it is important to understand how different this subsample of countries is from the rest of the European Union member states. Figures A.1 to A.6 (in Section A.3 of the Appendix) provide plots of our variable of interest (preferences for redistribution) and identity variables for the subgroup of countries that joined the EU after 2004 and those that joined before. In each case there appears to be little difference between the values in the two subsamples when plotted across interview years, but there appears to be evidence of convergence when we plot over sample waves. We may conclude that examining the subsample of countries is likely to allow us to identify the effect of an identity change in redistributive preferences.

Perhaps the most obvious problem in examining the effect of identity on redistributive preferences is the endogeneity of identity measures, and specifically the possibility of reverse causality whereby identity could be viewed as the effect of the existence of redistributive institutions. Furthermore, there might be unobservable variables that intermediate the association between identity and redistributive preferences. In order to account for the non-random changes in identity, we use an instrumental variable (IV) strategy that exploits the exogenous variation of a key institutional change, namely the introduction of the euro, which does not directly affect redistributive preferences unless it is by changing people's identification with Europe (the excludability condition). We also test for the so-called monotonicity condition to test whether the introduction of the euro did indeed affect identity in the expected sign and that the effect is strong (relevance condition) which is generally observed by examining the joint significance of first-stage estimates in a 2SLS (Staiger's condition).

Our IV strategy identifies the local average effects of the impact of identity changes resulting from the introduction of a common currency. In addition, we employ a battery of other instruments to examine whether the sign comparisons and results are equally robust. Finally, we undertake some placebo tests to make sure our results are not spurious.

We have estimated reduced forms of the effect of identity on redistributive preferences. Our identification rests on a combination of cross-sectional, time and cohort variation. In some specifications we run cohort-specific regressions to examine the potential cohort-specific effects. Country and time-specific trends are controlled for, as they could be driving the results. The regression strategy includes a quadratic trend to control for all those macroeconomic factors that are varying and exhibit a trend in time. Other country-specific time factors are expected to be captured by country fixed effects. 
The total number of observations is 27,376 . Our main dependent variable refers to redistributive preferences measured as before. Our treatment variable of interest refers to the two variables capturing the effect of identity, namely national pride and confidence in the EU. We include a long list of controls including demographics, income and socioeconomic, household size and employment status and we identify whether individual are immigrants to the country. The omitted categories in the regressions are male, elementary or lower education, all other marital statuses, no children, all other employment statuses and no immigrant status.

\section{Results}

\subsection{Preliminary Evidence}

Figures 1 and 2 provide data on the cohort and time trends on preference for redistribution in the sample of countries examined in this study. The cohort trend indicates that those individuals over 55 are more likely to support redistribution. Importantly, redistributive preferences have progressively become more salient in people's attitudes in recent survey waves. This effect is not just an artefact of the most recent wave.

Figure 1: Redistribution - cohort trend

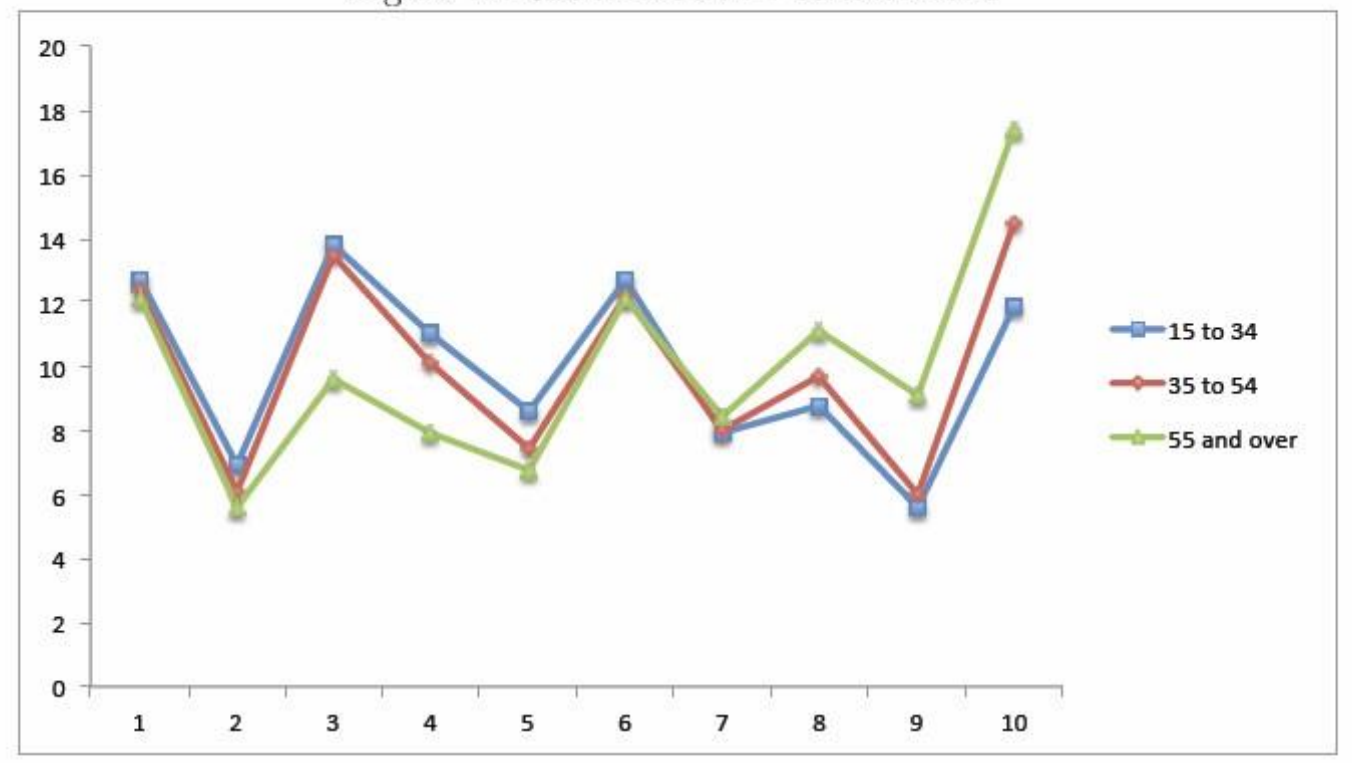

Note: Figure shows attitudes towards redistribution for different age groups, with 1 being "we need larger income differences as incentives for individual effort" and 10 being "incomes should be made more equal". Data are from the sample of countries which joined the European Union after 2003 (responses shown in percent, $\mathrm{n}=25,216$ ). 
Figure 2: Redistribution - time trend

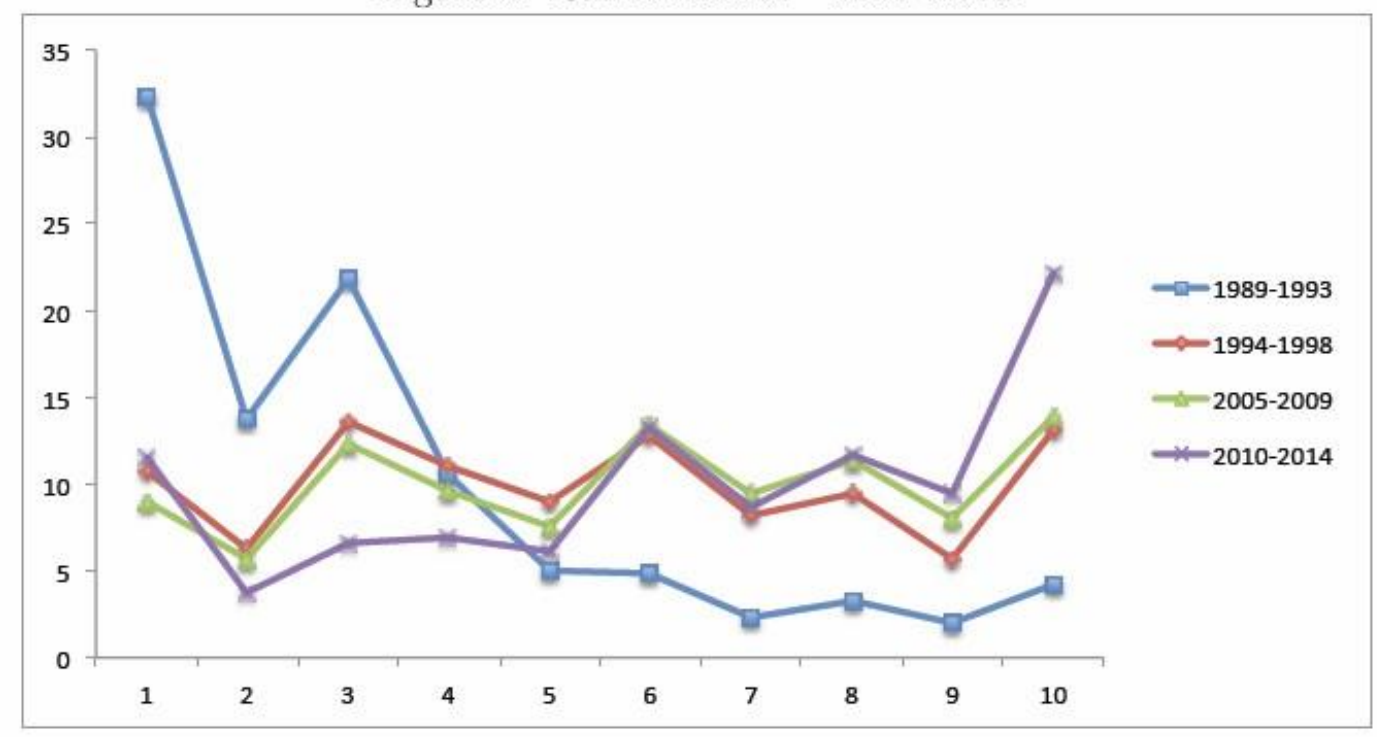

Note: Figure shows attitudes towards redistribution for different survey waves, with 1 being "we need larger income differences as incentives for individual effort" and 10 being "incomes should be made more equal". Data are from the sample of countries which joined the European Union after 2003 (responses shown in percent, $\mathrm{n}=25,216$ ).

Figures 3 and 4 examine similar trends in national pride indicating an age component to it, which is in line with the hypothesis of Europeanisation as reducing national pride: Europeanisation may have reduced national attachment. Some research finds time trend identification with Europe in EU countries (Fligstein et al. 2012), but identification appears to be largely dependent on the economic performance of Europe, particularly unemployment (Guiso et al. 2014). Some recent evidence finds that Eastern European countries exhibited a comparable or even higher identification with Europe which is in large part explained by the large minority groups in many of those European member states.

Figures 5 and 6 examine cohort and time trends on EU confidence. Measuring the importance of confidence in the EU is important, because being European can mean different things across countries whilst confidence with the EU is a commonly accepted construct. Interestingly cohort trends show that younger cohorts are more likely to identify with Europe, exactly the opposite trend to that of national pride. In contrast, we find that time trends suggest a slight reduction in EU confidence. This result is consistent with the idea advanced by Fligstein et al. (2012) that European identity is a class-based phenomenon directly linked to the transnational mobility benefits of the common EU market. However, the rise of European identity might be the effect of educational attainment and increasing cultural interconnection. To disentangle such effect we need additional regression analysis. 
Figure 3: National pride - cohort trend

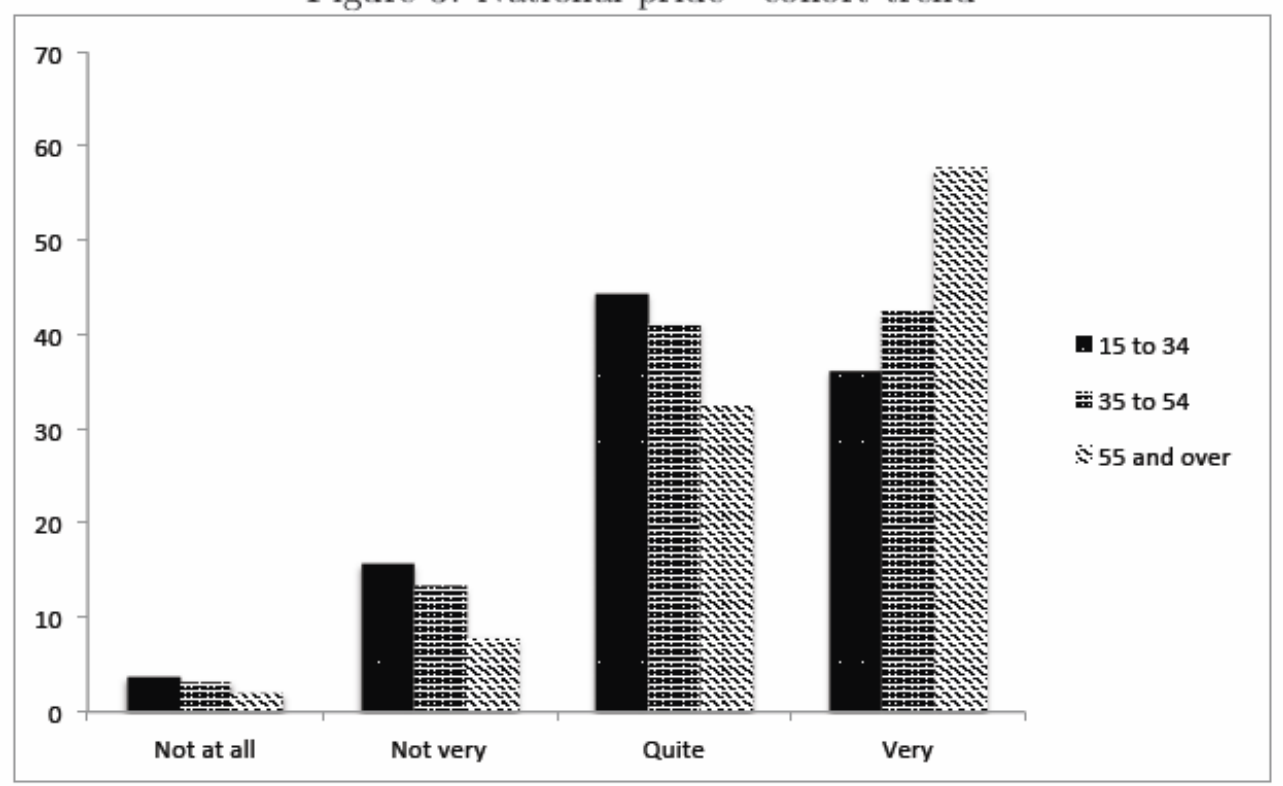

Note: Figure shows responses to the question "How proud are you to be [nationality]?" for different survey waves. Data are from the sample of countries which joined the European Union after 2003 (responses shown in percent, $\mathrm{n}=26,025$ ).

Figure 4: National pride - time trend

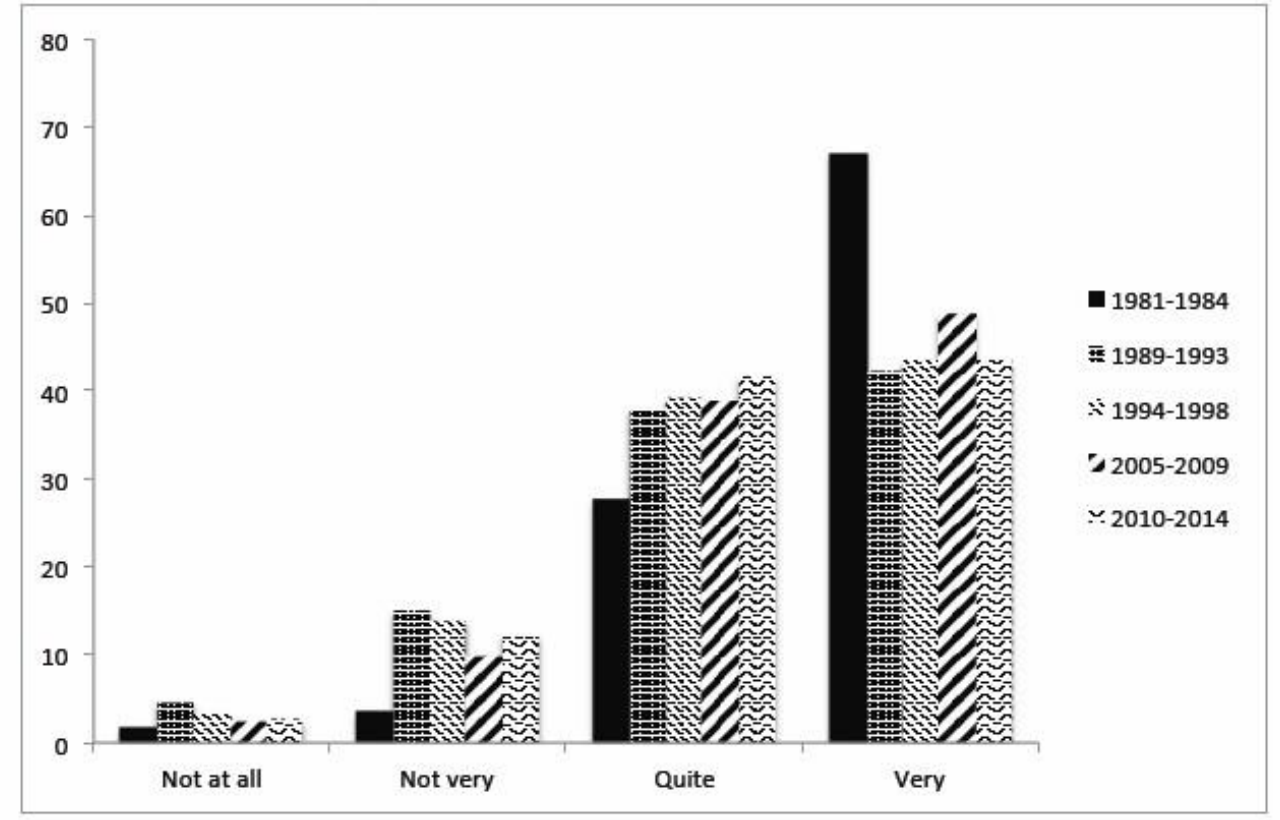

Note: Figure shows responses to the question "How proud are you to be [nationality]?" for different age groups. Data are from the sample of countries which joined the European Union after 2003 (responses shown in percent, $\mathrm{n}=26,025$ ). 
Figure 5: Confidence in the EU - cohort trend

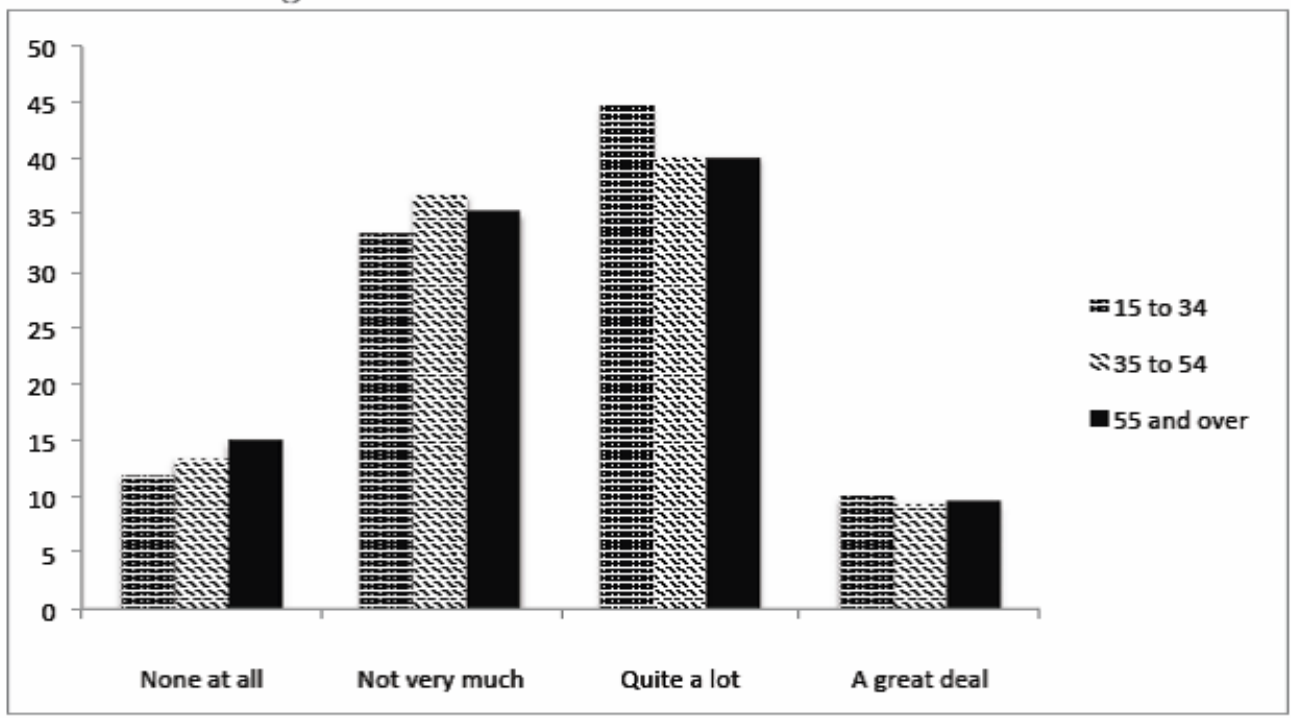

Note: Figure shows responses to the question "Could you tell me how much confidence you have in [the European Union]?" for different age groups. Data are from the sample of countries which joined the European Union after 2003 (responses shown in percent, $\mathrm{n}=20,795$ ).

Figure 6: Confidence in the EU - time trend

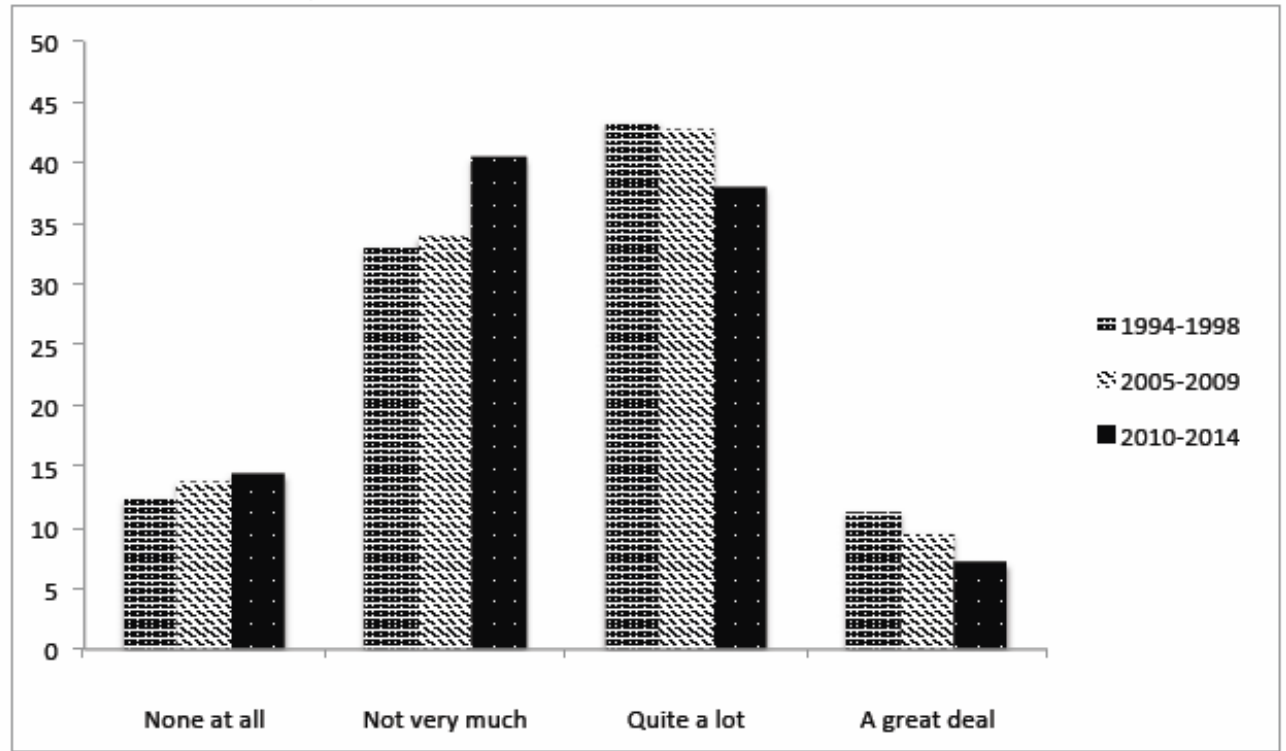

Note: Figure shows responses to the question "Could you tell me how much confidence you have in [the European Union]?" for different survey waves. Data are from the sample of countries which joined the European Union after 2003 (responses shown in percent, $\mathrm{n}=20,795$ ). 


\subsection{Baseline results}

\section{Specifications}

Our baseline specification is the following:

$$
R_{i}=\gamma_{0}+\gamma_{1} I_{i t r}+\gamma_{2} X_{i t r}+\gamma_{3} y_{i t r}+\delta_{r}+\theta_{t}+\varepsilon_{i t r}
$$

where $R_{i t r}$ refers to the preference-for-redistribution response by an individual $i$, interviewed at time $t$ and in country $r$. The variable ${ }_{t r}$ refers to a variable indicating individuals' European identity, measured as the individual identification with their country (national pride) or Europe (confidence in the European Union). All specifications include a vector of individual characteristic $X_{i t r}$ which includes age, gender, schooling, civil status, size of the area of residence; ${ }^{15} y_{i t r}$ is included to control for changes in income $\tilde{A}$ la Meltzer and Richard as well as unemployment as potentially driving the results; $\delta_{r}$ refers to country fixed effects to control for common background of individuals residing in each country, $\theta_{t}$ refers to a wave- (time-) specific effect to control for age- specific trends in redistributive preferences and $\varepsilon_{i t r}$ is a random term. where euro refers to a dummy variable taking the value 1 if the country $r$ has adopted the common currency at time $t$ and a vector of individual characteristics $\left(Z_{i}\right)$. As a rule-of-thumb the F-test of such a first regression should exceed the value 10 for the instrument to be strong enough to meet the relevance condition. In addition, the excludability condition refers to the absence of a correlation between the error term and the instrument. This condition cannot be tested empirically, but we do address some issues concerning this assumption by testing the effects of alternative instruments that follow a similar rationale, and examining different of suggestive evidence on its plausibility.

All regressions have been estimated using OLS to ease the interpretation of coefficients, and robustness checks include specifications using alternative techniques dealing with the categorical nature of the data, including a binarised identity and redistributive preference variable so as to interpret the dependent variable as a probability. Robust standard errors are clustered at the country level and descriptive statistics are provided in Tables A.1 and A.2 of the Appendix

In order to estimate the 2SLS equation we employ a first-stage equation capturing the impact of the proposed instrument on the identity questions:

$$
I_{i t r}=\alpha_{0}+\alpha_{1} \text { euro }_{t r}+\alpha_{2} X_{i}+\alpha_{3} Z_{i}+\mu_{i t r}
$$

$\overline{15}$ Although the notation allows for individual $i$, interviewed at time $t$ and in country $r$ some of these characteristics are time-invariant. 


\section{Baseline regressions}

Table 1 reports the regression results to explain redistributive preferences by change in national pride and EU confidence. These are OLS results that do not take into account all the potential problems of reverse causality and omitted- variable bias. We provide different specifications with different controls and the beta coefficients to interpret the results as the effects of a one-standard- deviation change. The effects of income are as expected, indicated by a negative and significant coefficient.

A one-standard-deviation increase in national pride is found to reduce redistributive preferences by the same magnitude $(6 \%)$ as a one-standard- deviation increase in income. As expected, younger individuals are more likely to support redistribution. A onestandard-deviation increase in the population in tertiary education reduces preferences for redistribution by $13 \%$. So the effect of education appears to be twice the size of the effect of income. This is an important result, given the focus in the literature on the Meltzer and Richard type of approach. Indeed, this coefficient is important as it can explain why the income ranking of the median voter would not exert the predicted influence. Initially, Columns (1) and (6) report only the coefficient for national pride and confidence in the EU respectively. The regressions contained in columns (2) and (7) report the effect after the introduction of a quadratic time trend to account for potential underlying trends that could be driving the coefficients. Columns (3) and (8) contain the effect of adding additional controls for income and employment, and finally Columns (4) and (9) contain the effect resulting from the additional control for town size. All regressions contain country fixed effects. Overall, the coefficients for national pride exhibit little variation in its size. Importantly, unemployment which is a variable that is found to explain European identification and trust in European institutions (Guiso et al. 2014) does not exert an influence on preferences for redistribution. From all the covariates reported here the most important determinant of redistributive preferences appears to be education.

Table 2 reports a 2SLS instrumental variable (IV) analysis that controls for reverse causality and unobservables. Now confidence in the EU switches its coefficient to being positive and significant and exhibits the same coefficient size but with the opposite sign to that of national pride (both are statistically significant). Again, the effect's size indicates that one standard deviation of national pride reduces preferences for redistribution by an amount similar in size (but opposite in sign) to that of an increase in confidence in the EU. Tests all reject the hypothesis of exogeneity, and the F-test of the first stage regression both exceed 10 suggesting that instruments are not weak. Furthermore, the instrument (join the euro) exhibits the expected sign. As expected, looking at the first stage regression we find that women, older individuals, married 
and people without tertiary education, unemployed and from smaller towns are more likely to exhibit national pride.

As expected the coefficient for tertiary education remains strongly significant and negatively associated with redistributive preferences. Interestingly, income and tertiary education have an opposite effect on national pride. Again all regressions control for country fixed effects. Some important differences across specifications when national pride and confidence in the EU are estimated refer to the effect of age, which only the effect of age squared turns out to be significant when explaining national pride. In contrast, age exhibits a reverse nonlinear effect in explaining confidence in the EU and redistributive preferences. The pattern of coefficients in Table 0 remains in Table 1 when redistributive preferences are binarised. The interpretation is that the probability of supporting redistribution declines by $2.5 \%$ if individuals exhibit national pride, and increases by the same magnitude if they have confidence in the EU. Tables 6.4 and 11 in the Appendix show that this effect is primarily driven by older-age and low- income individuals. On this basis we can conclude that the the instrumental strategy we employ appears to provide consistent and robust results, given that alternative instruments provide similar results.

\subsection{Robustness checks}

Tables 4 and 5 report the regression estimates using different instruments. In Table 4 we use alternative instruments of EU confidence such as a dummy indicating whether the country has joined the EU, average confidence in the EU (of other countries in the sample) to predict confidence and average pride (of other countries in the sample) to predict pride. The exogeneity and $\mathrm{F}$ tests coefficients all suggest they are not weak instruments and the coefficients are all exhibiting the same sign although vary in terms of the impact. An expansion of EU confidence exerts a larger positive effect now than the negative effects of national pride. Then in Table 3 we examine other instruments such as the duration of citizenship education, which turns out to be a weak instrument, and the number of medals in the Olympics games which was a strong instrument for national pride and results in the IV analysis showing a significant and comparable coefficient as in other regressions estimates.

Table 6 shows that the estimates predicting redistributive preferences are robust to the inclusion of political preferences. As before, the inclusion of different instruments suggests the same reverse-sign effect in the coefficient for EU confidence which now turns positive when including the political control in the estimates with the alternative instruments used in Table 3. As expected, the more to the right an individual positions himself the less likely he is to support redistribution. All estimates exhibit an important nonlinear trend which captures among other effects that of time-varying macroeconomic and contextual effects. 
Table 1: OLS baseline results

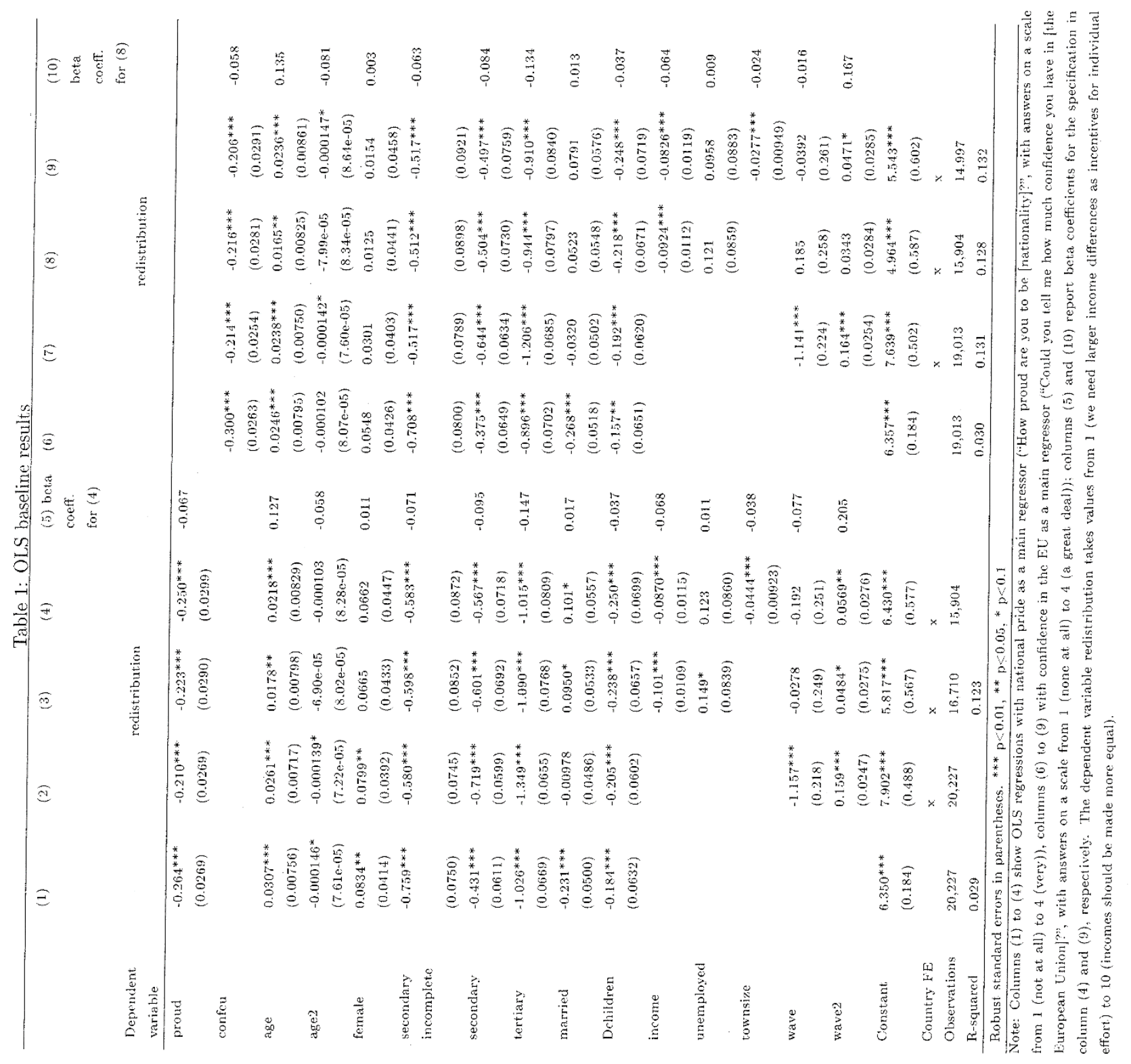


Table 2 IV baseline results

Table 2: IV baseline results

\begin{tabular}{|c|c|c|c|c|}
\hline & (1) & (2) & (3) & (4) \\
\hline Dependent variable & $\begin{array}{l}\text { 1st stage } \\
\text { proud }\end{array}$ & $\begin{array}{l}\text { 2nd stage } \\
\text { redistribution }\end{array}$ & $\begin{array}{l}\text { 1st stage } \\
\text { confeu }\end{array}$ & $\begin{array}{l}\text { 2nd stage } \\
\text { redistribution }\end{array}$ \\
\hline \multirow[t]{2}{*}{ joineuro } & $-0.127^{* * *}$ & & $0.119^{* * *}$ & \\
\hline & $(0.0304)$ & & $(0.0366)$ & \\
\hline \multirow[t]{2}{*}{ proud } & & $-15.58 * * *$ & & \\
\hline & & $(3.788)$ & & \\
\hline \multirow[t]{2}{*}{ confeu } & & & & $16.49^{* * *}$ \\
\hline & & & & $(5.242)$ \\
\hline \multirow[t]{2}{*}{ age } & -0.000967 & 0.00607 & $-0.0 .152 * * *$ & $0.277^{* * *}$ \\
\hline & $(0.00227)$ & $(0.0359)$ & $(0.00260)$ & $(0.0907)$ \\
\hline \multirow[t]{2}{*}{ age 2} & $7.73 \mathrm{e}-05^{* * *}$ & $0.00109^{* *}$ & $0.000150^{* * *}$ & $-0.00265^{* * *}$ \\
\hline & $(2.23 \mathrm{e}-05)$ & $(0.000461)$ & $(2.60 \mathrm{c}-05)$ & $(0.000900)$ \\
\hline \multirow[t]{2}{*}{ female } & $0.0473^{* * *}$ & $0.794^{* * *}$ & $-0.0236^{*}$ & 0.411 \\
\hline & $(0.0120)$ & $(0.260)$ & $(0.0137)$ & $(0.265)$ \\
\hline \multirow[t]{2}{*}{ secondary incomplete } & -0.00933 & $-0.680^{* *}$ & 0.0136 & -0.695 \\
\hline & $(0.0217)$ & $(0.341)$ & $(0.0269)$ & $(0.459)$ \\
\hline \multirow[t]{2}{*}{ secondary } & -0.0263 & $-0.909^{* * *}$ & 0.00447 & -0.506 \\
\hline & $(0.0183)$ & $(0.298)$ & $(0.0228)$ & $(0.387)$ \\
\hline \multirow[t]{2}{*}{ tertiary } & $-0.0808^{* * *}$ & $-2.183^{* * *}$ & $0.0630^{* *}$ & $-1.885 * * *$ \\
\hline & $(0.0216)$ & $(0.444)$ & $(0.0254)$ & $(0.524)$ \\
\hline \multirow{2}{*}{ married } & $0.0465^{* * *}$ & $0.802 * * *$ & -0.00880 & 0.216 \\
\hline & $(0.0152)$ & $(0.292)$ & $(0.0173)$ & $(0.298)$ \\
\hline \multirow[t]{2}{*}{ Dehildren } & -0.0220 & $-0.566^{*}$ & 0.0160 & -0.493 \\
\hline & $(0.0195)$ & $(0.315)$ & $(0.0221)$ & $(0.384)$ \\
\hline \multirow[t]{2}{*}{ income } & $0.00935^{* * *}$ & 0.0606 & $0.0335^{* * *}$ & $-0.638^{* * *}$ \\
\hline & $(0.00307)$ & $(0.0603)$ & $(0.00347)$ & $(0.184)$ \\
\hline \multirow[t]{2}{*}{ unemployed } & $-0.110^{* * *}$ & $-1.568 * * *$ & $-0.0492^{*}$ & $0.913^{*}$ \\
\hline & $(0.0246)$ & $(0.568)$ & $(0.0266)$ & $(0.521)$ \\
\hline \multirow[t]{2}{*}{ townsize } & $-0.0234^{* * *}$ & $-0.404 * * *$ & $0.0126^{* * *}$ & $-0.239^{* * *}$ \\
\hline & $(0.00255)$ & $(0.0972)$ & $(0.00283)$ & $(0.0829)$ \\
\hline \multirow[t]{2}{*}{ wave } & $-0.356^{* * * *}$ & $-2.863^{* *}$ & $0.268^{* * *}$ & -1.544 \\
\hline & $(0.0786)$ & $(1.230)$ & $(0.0959)$ & $(1.419)$ \\
\hline \multirow[t]{2}{*}{ wave 2} & $0.0367^{* * *}$ & $0.288^{* *}$ & $-0.0367^{* * *}$ & $0.307^{*}$ \\
\hline & $(0.00874)$ & $(0.126)$ & $(0.0107)$ & $(0.165)$ \\
\hline \multirow[t]{2}{*}{ Constant } & $3.989^{* * *}$ & $62.00^{* * *}$ & $2.427^{* * *}$ & $-40.93^{* * *}$ \\
\hline & $(0.173)$ & $(13.94)$ & $(0.213)$ & $(14.90)$ \\
\hline Country FE & $\mathrm{x}$ & $\mathrm{x}$ & $\mathrm{x}$ & $\mathrm{x}$ \\
\hline Observations & 15,904 & 15,904 & 14,997 & 14,997 \\
\hline R-squared & 0.117 & -14.693 & 0.045 & -21.308 \\
\hline \multicolumn{3}{|c|}{ Robust standard errors in parentheses } & \multicolumn{2}{|c|}{${ }^{* * *} \mathrm{p}<0.01,{ }^{* *} \mathrm{p}<0.05, * \mathrm{p}<0.1$} \\
\hline \multicolumn{5}{|c|}{ Test of excluded instruments: } \\
\hline \multirow{2}{*}{\multicolumn{3}{|c|}{$\begin{array}{l}F(1,15880)=17.58 \\
\text { Prob }>F=0.0000\end{array}$}} & \multicolumn{2}{|l|}{$\mathrm{F}(1,14973)=10.54$} \\
\hline & & & \multicolumn{2}{|l|}{ Prob $>F=0.0012$} \\
\hline Endogeneity test of end & ogenous regressors: & & & \\
\hline & 238.875 & & 238.148 & \\
\hline & Chi-sq(1) P-val $=0.0 \Phi \overline{00}$ & & Chi-sq(1) P-val $=0.0000$ & \\
\hline
\end{tabular}

Note: Table shows the 1st and 2 nd stage of instrumental variables regression. The instrument is

the binary variable joineuro, taking a value of 1 if the country is part of the euro currency in the respective year. Columns (1) and (2) use national pride as the instrumented variable, columns (3) and (4) use confidence in the EU as the instrumented variable. The dependent variable redistribution takes values from 1 (we need larger income differences as incentives for individual effort) to 10 (incomes should be made more equal). 
Table 3: Redistribution binarised

Table 3: Redistribution binarised

\begin{tabular}{|c|c|c|c|c|}
\hline & (1) & (2) & (3) & (4) \\
\hline Dependent variable & $\begin{array}{l}\text { 1st stage } \\
\text { proud }\end{array}$ & $\begin{array}{l}\text { 2nd stage } \\
\text { redistribution_binary }\end{array}$ & $\begin{array}{l}\text { 1st stage } \\
\text { confeu }\end{array}$ & $\begin{array}{l}\text { 2nd stage } \\
\text { redistribution_binary }\end{array}$ \\
\hline joineuro & $\begin{array}{l}-0.127 * * * \\
(0.0304)\end{array}$ & & $\begin{array}{l}0.119^{* * *} \\
(0.0366)\end{array}$ & \\
\hline proud & & $\begin{array}{l}-2.416^{* * *} \\
(0.589)\end{array}$ & & \\
\hline confeu & & & & $\begin{array}{l}2.568^{* * *} \\
(0.816)\end{array}$ \\
\hline Country FE & $\mathrm{x}$ & $\mathrm{x}$ & $x$ & $\mathrm{x}$ \\
\hline Observations & 15904 & 15904 & 14997 & 14997 \\
\hline R-squared & 0.117 & -12.486 & 0.045 & -18.217 \\
\hline
\end{tabular}

Robust standard errors in parentheses

*** $\mathrm{p}<0.01,{ }^{* *} \mathrm{p}<0.05,{ }^{*} \mathrm{p}<0.1$.

Test of excluded instruments:

$$
\begin{array}{ll}
F(1,15880)=17.58 & F(1,14973)=10.54 \\
\text { Prob }>F=0.0000 & \text { Prob }>F=0.0012
\end{array}
$$

Endogeneity test of endogenous regressors:

$$
\begin{array}{ll}
221.336 & 221.036 \\
\text { Chi-sq(1) P-val }=0.0000 & \text { Chi-sq(1) P-val }=0.0000
\end{array}
$$

Note: Table shows the 1 st and 2 nd stage of instrumental variables regression. The instrument is the binary variable joineuro, taking a value of 1 if the country is part of the euro currency in the respective year. Columns (1) and (2) use national pride as the instrumented variable, columns (3) and (4) use confidence in the EU as the instrumented variable; redistribution_binary $=0$ if attitude towards redistribution between 1 and 5 , and $=1$ if attitude towards redistribution between 6 and 10, with 1 being "we need larger income differences as incentives for individual effort" and 10 being "incomes should be made more equal"; independent variables included are: age, age squared, female, secondary incomplete, secondary, tertiary, married, children, income, unemployed, town size, wave, and wave squared. 


\section{Table 4: Additional instruments I}

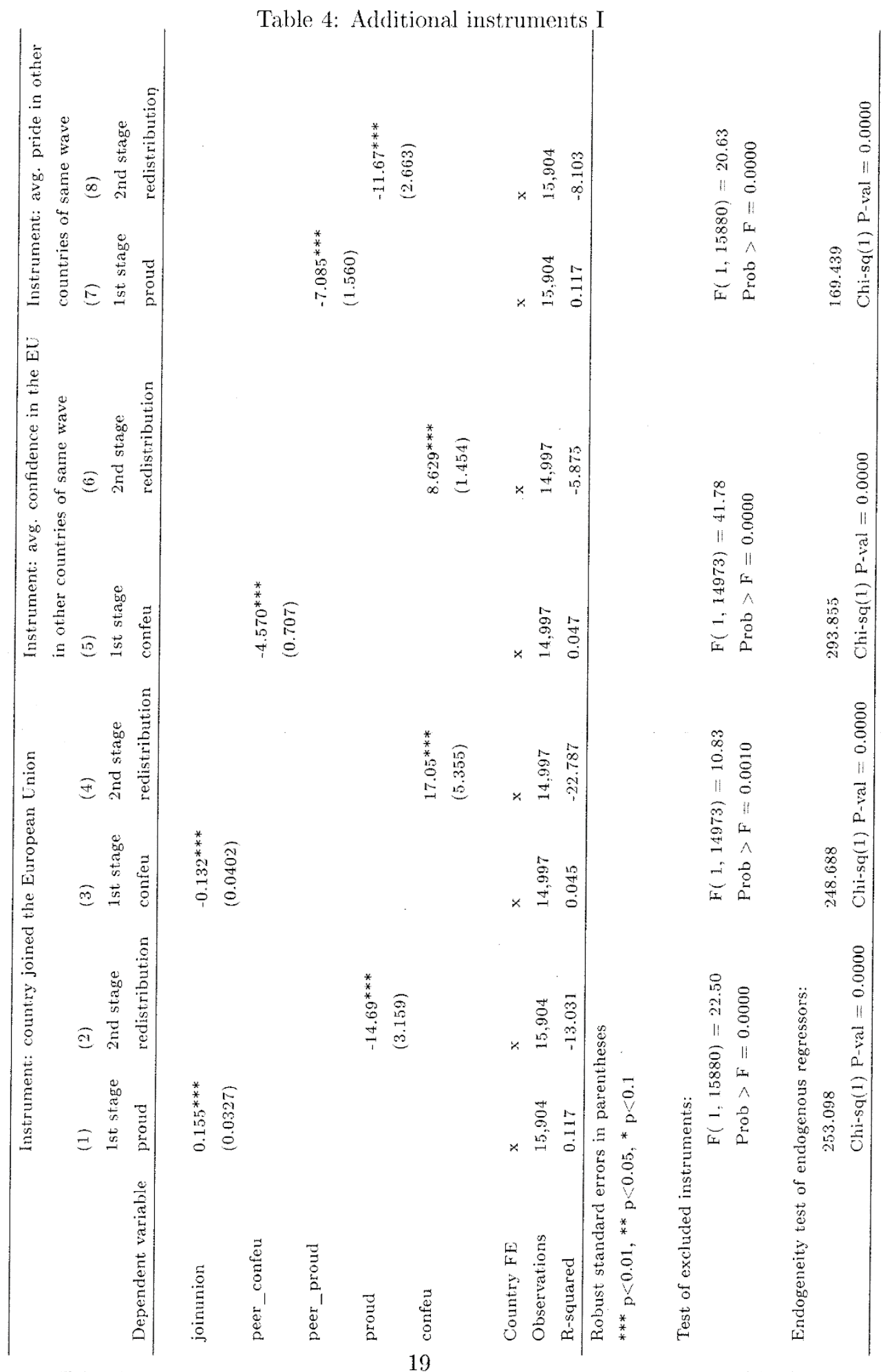

Note: Table shows the 1 st and 2 nd stage of IV regression for alternative instruments; cols (1)-(4) use the binary variable joinunion, taking the value of 1 if the country is part of the EU in the respective year; cols (5), (6) use peer_confeu, indicating the average confidence in the EU in all other countries of the same wave; cols $(7),(8)$ use average national pride in all other countries of the same wave. The dependent variable redistribution takes values from 1 (we need larger income differences as incentives for individual effort) to 10 (incomes slould be made more equal); independent variables included are age, age squared, female, secondary incomplete, secondary, tertiary, married, children, income. unemnloved. town size. wave. and wave smared. 
Table 5: Additional instruments II

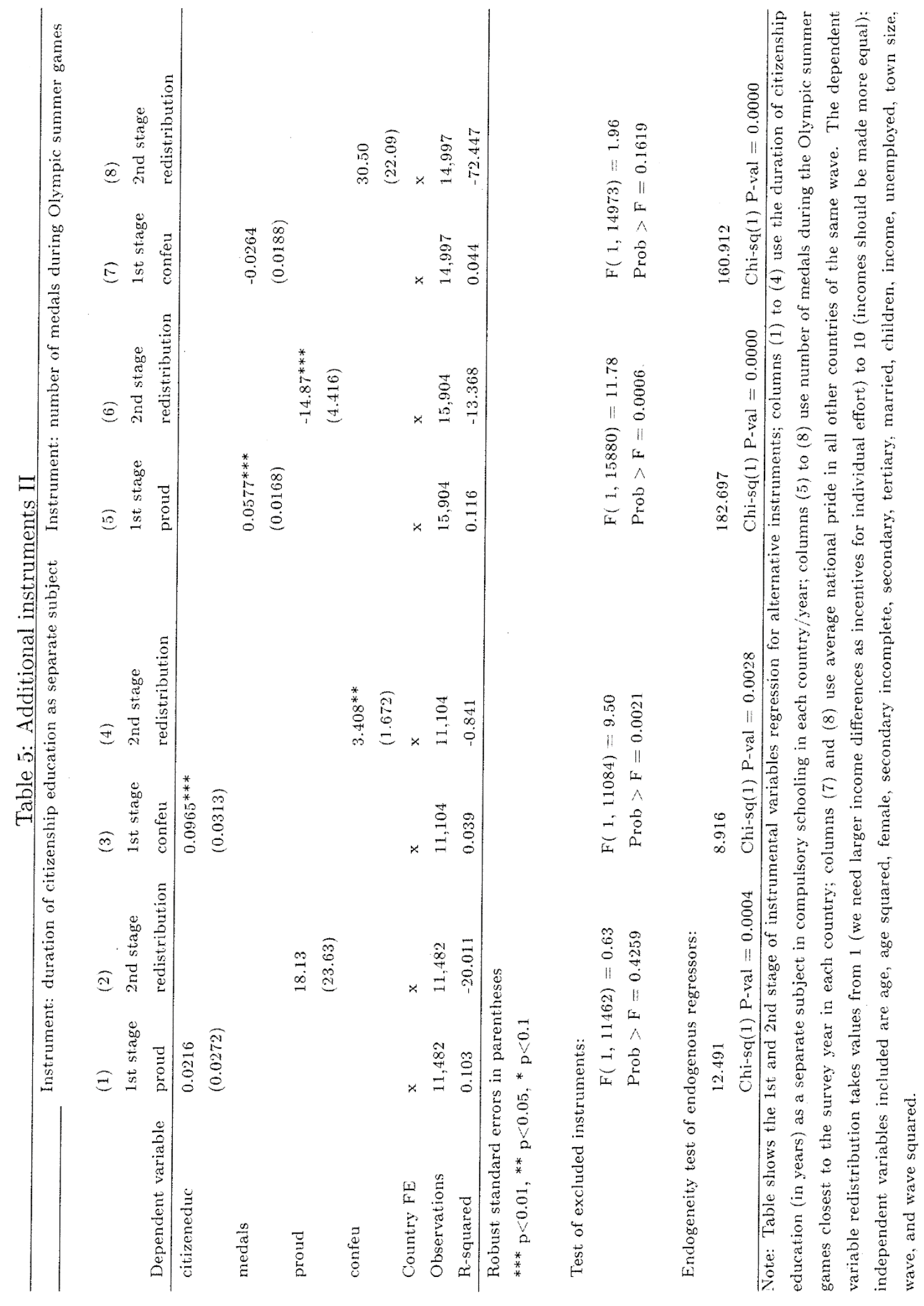


Table 6: Additional covariates

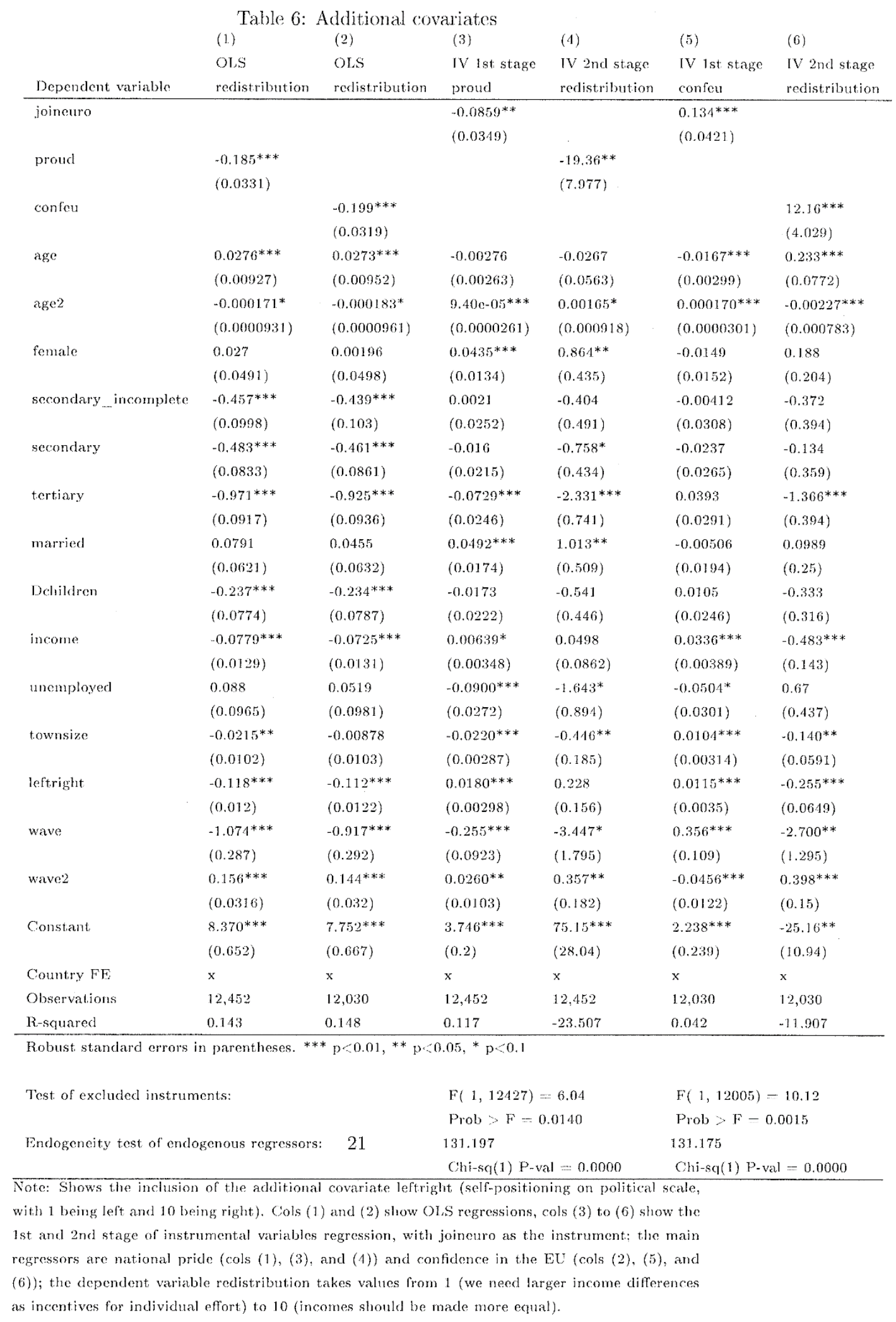




\section{Conclusion}

The rescaling of spatial identity in the context of European integration processes is potentially an important effect underpinning changes in redistributive preferences. This paper has provided evidence to support that claim. However, unlike previous research that mainly stresses the importance of group identity, we have argued that the scale of geographical identification matters. Specifically, the development of a European identity appears to weaken national pride. But how important is this new collective identity in shifting preferences for redistribution? The answer to this question could help to explain the limited evidence of median-voter explanations for redistributive preferences. Indeed, in addition to the information problems people face in identifying their position in the income distribution, when making redistributive judgments, they appear to react to change in the spatial scale of reference. So the expansion of the European integration process together with the introduction of a common currency exerts a non-neutral influence in the context that influences redistributive preferences.

This paper has specifically examined the effects of spatial identity in those countries that joined the EU after 2004 where we can identify the introduction of reforms expanding European integration and the effect of joining the single currency. Unlike the case of the founding countries of the Eurozone we can identify the effect of joining a European club more precisely using the recent- joiners sample. We find a positive (negative) impact of European identity (national identity) on preferences for redistribution. The effect of identity is comparable in size to the effect of income and is only exceeded by the effect of tertiary education.

These results indicate that institutional changes involving symbolic features that define one's identity - in this case the currency - can exert an impact on people's attachments, and more specifically can underpin the formation of a person's identity. We find robust evidence suggesting that the introduction of the euro as a common currency in countries that joined the EU after 2004 increased people's confidence in the European Union, and reduced the importance of national pride. Similarly, this evidence is replicated when other potential identity instruments are examined. Using an instrumental variable strategy, we find that the exogenous change in European identity resulting from a common currency increases people's preference for redistribution. These results are consistent with the previous identity literature. ${ }^{16}$

Among the policy implications of these findings it appears that there are important positive knock-on effects on redistributive preferences associated with furthering European integration. The lessening of national pride is more likely to lead to changes in individuals' reference points which influence the way they form preferences for redistribution

16 See Shayo (2009) and Costa-Font and Cowell (2015) for a review. 
Table 7: OLS results - restricted sample without Latvia and Lithuania

\begin{tabular}{|c|c|c|c|c|c|c|c|c|c|c|}
\hline Dependent var. & (1) & (2) & (3) & (4) & $\begin{array}{c}\text { (5) } \\
\text { beta coeff. } \\
\text { for (4) } \\
\text { redist }\end{array}$ & (5) & (6) & (7) & (8) & $\begin{array}{c}(10) \\
\text { beta ooeff. } \\
\text { for }(9)\end{array}$ \\
\hline proud & $\begin{array}{c}-0.291 \cdots \\
(0.0293)\end{array}$ & $\begin{array}{c}-0.177^{* \cdots} \\
\langle 0.0289\rangle\end{array}$ & $\begin{array}{l}0.194 \cdots \\
(0.0314)\end{array}$ & $\begin{array}{l}-0.222 * \cdots \\
(0.0325)\end{array}$ & -0.0567 & & & & & \\
\hline confeu & & & & & & $\begin{array}{c}-0.295^{* \cdots} \\
(0.0273)\end{array}$ & $\begin{array}{l}-0.207^{* \times 2} \\
(0.0265)\end{array}$ & $\begin{array}{l}-0.212^{* * *} \\
(0.0295)\end{array}$ & $\begin{array}{l}0.202^{* \cdots} \\
(0.0306)\end{array}$ & -0.0577 \\
\hline age & $\begin{array}{c}0.0314^{* * x} \\
\langle 0.00796\rangle\end{array}$ & $\begin{array}{l}0.0257 \times \times 5 \\
(0.00755)\end{array}$ & $\begin{array}{l}0.0184^{*} \\
(0.00846)\end{array}$ & $\begin{array}{l}0.0223^{* *} \\
(0.00885)\end{array}$ & 0.1294 & $\begin{array}{l}0.0257^{* \times *} \\
(0.00836)\end{array}$ & $\begin{array}{c}0.0229^{\times \times x} \\
(0.00790)\end{array}$ & $\begin{array}{c}0.0170^{*} \\
\langle 0.00873)\end{array}$ & $\begin{array}{l}0.0245^{*-1} \\
(0.00918)\end{array}$ & 0.1397 \\
\hline $\operatorname{agc} 2$ & $\begin{array}{c}-0.000159^{* \times} \\
(7.960-0.5)\end{array}$ & $\begin{array}{l}-0.000141^{*} \\
(7.560-05)\end{array}$ & $\begin{array}{l}-7.94 e-05 \\
(8.45 e-05)\end{array}$ & $\begin{array}{l}-0.000115 \\
(8.760-05)\end{array}$ & -0.0649 & $\begin{array}{l}-0.000120 \\
(8.44 \mathrm{e}-0.5)\end{array}$ & $\begin{array}{l}-0.000138 * \\
(7.960-05)\end{array}$ & $\begin{array}{r}-8.69 e-05 \\
(8.76 e-05)\end{array}$ & $\begin{array}{l}-0.000159^{*} \\
(9.14 \mathrm{e}-05)\end{array}$ & -0.0860 \\
\hline female & $\begin{array}{c}0.0981^{*} \\
(0.0437)\end{array}$ & $\begin{array}{c}0.0836^{*-} \\
(0.0414)\end{array}$ & $\begin{array}{c}0.0690 \\
(0.0460)\end{array}$ & $\begin{array}{c}0.0671 \\
(0.0477)\end{array}$ & 0.0113 & $\begin{array}{c}0.0646 \\
(0.0448)\end{array}$ & $\begin{array}{c}0.0324 \\
(0.0424)\end{array}$ & $\begin{array}{c}0.0144 \\
(0.0467)\end{array}$ & $\begin{array}{c}0.0163 \\
(0.0487)\end{array}$ & 0.0027 \\
\hline second._incomp. & $\begin{array}{l}-0.818^{2 \cdots} \\
(0.0775)\end{array}$ & $\begin{array}{l}-0.632 * \cdots \\
(0.0771)\end{array}$ & $\begin{array}{l}-0.667 * \cdots \\
(0.0888)\end{array}$ & $\begin{array}{l}-0.663^{* \cdots} \\
(0.0910)\end{array}$ & -0.0807 & $\begin{array}{l}-0.759^{\cdots \cdots} \\
(0.0821)\end{array}$ & $\begin{array}{l}-0.565 \cdots * \\
\langle 0.0811\rangle\end{array}$ & $\begin{array}{l}-0.575 \cdots \\
(0.0928)\end{array}$ & $\begin{array}{l}-0.588 \cdots \\
(0.0953)\end{array}$ & $=0.0719$ \\
\hline sesondary & $\begin{array}{c}-0.361^{\cdots *} \\
(0.0628)\end{array}$ & $\begin{array}{c}-0.710^{2 \times x} \\
(0.0616)\end{array}$ & $\begin{array}{c}-0.597^{* \cdots} \\
(0.0716)\end{array}$ & $\begin{array}{c}-0.576 \cdots \\
(0.0746)\end{array}$ & -0.0960 & $\begin{array}{c}-0.306^{* \cdots} \\
(0.0665)\end{array}$ & $\begin{array}{l}-0.644^{* \times x} \\
(0.0650)\end{array}$ & $\begin{array}{c}-0.504 * \cdots \\
(0.0751)\end{array}$ & $\begin{array}{l}-0.506^{\cdots} \\
(0.0784)\end{array}$ & -0.0846 \\
\hline tertiary & $\begin{array}{l}-0.947^{* * \times} \\
(0.0695)\end{array}$ & $\begin{array}{c}-1.331 \cdots 6 \\
(0.0679)\end{array}$ & $\begin{array}{c}-1.090^{* \cdots} \\
(0.0802)\end{array}$ & $\begin{array}{l}-1.032 * \ldots \\
(0.0850)\end{array}$ & -0.1476 & $\begin{array}{c}-0.816^{* \cdots} \\
(0.0727)\end{array}$ & $\begin{array}{c}-1.205 * \cdots \\
(0.0709)\end{array}$ & $\begin{array}{l}-0.956^{\cdots \cdots} \\
(0.0828)\end{array}$ & $\begin{array}{l}-0.936^{* *} \\
(0.0878)\end{array}$ & -0.1360 \\
\hline married & $\begin{array}{c}-0.292^{* \cdots} \\
(0.0529)\end{array}$ & $\begin{array}{r}-0.0315 \\
(0.0516)\end{array}$ & $\begin{array}{c}0.0550 \\
(0.0571)\end{array}$ & $\begin{array}{c}0.0652 \\
(0.0600)\end{array}$ & 0.0108 & $\begin{array}{c}-0.335 * \cdots \\
(0.0545)\end{array}$ & $\begin{array}{r}0.0488 \\
\langle 0.0531)\end{array}$ & $\begin{array}{c}0.0222 \\
(0.0582)\end{array}$ & $\begin{array}{c}0.0532 \\
(0.0617)\end{array}$ & 0.0088 \\
\hline Dehildren & $\begin{array}{l}0.156^{* *} \\
(0.0672)\end{array}$ & $\begin{array}{c}-0.191^{* \ldots 6} \\
\langle 0.0643\rangle\end{array}$ & $\begin{array}{c}-0.231 * \times x \\
(0.0708)\end{array}$ & $\begin{array}{c}-0.237^{* \cdots *} \\
(0.0761)\end{array}$ & -0.0345 & $\begin{array}{c}-0.113 \\
(0.0688)\end{array}$ & $\begin{array}{l}0.167^{* *} \\
\langle 0.0658\rangle\end{array}$ & $\begin{array}{c}-0.201 * \times * \\
(0.0717)\end{array}$ & $\begin{array}{c}0.231 \cdots \\
(0.0776)\end{array}$ & -0.0342 \\
\hline income & & & $\begin{array}{c}-0.0854^{* \cdots} \\
(0.0119)\end{array}$ & $\begin{array}{c}-0.0802^{2 \times-} \\
(0.0127)\end{array}$ & -0.0599 & & & $\begin{array}{c}-0.0877 \times \cdots \\
(0.0122)\end{array}$ & $\begin{array}{c}-0.0767 \times * \\
(0.0131)\end{array}$ & -0.0566 \\
\hline unemployed & & & $\begin{array}{c}0.135 \\
(0.0894)\end{array}$ & $\begin{array}{c}0.107 \\
(0.0921)\end{array}$ & 0.0093 & & & $\begin{array}{c}0.115 \\
(0.0908)\end{array}$ & $\begin{array}{c}0.0870 \\
(0.0937)\end{array}$ & 0.0076 \\
\hline townsize & & & & $\begin{array}{c}-0.0371^{\cdots} \\
(0.0101)\end{array}$ & -0.0311 & & & & $\begin{array}{c}-0.0218^{* *} \\
(0.0104)\end{array}$ & -0.0183 \\
\hline wave & & $\begin{array}{c}-1.145^{* \cdots} \\
(0.218)\end{array}$ & $\begin{array}{r}-0.0302 \\
(0.249)\end{array}$ & $\begin{array}{l}-0.198 \\
\langle 0.251\rangle\end{array}$ & -0.0716 & & $\begin{array}{c}-1.137 * \times \times \\
(0.224)\end{array}$ & $\begin{array}{c}0.179 \\
(0.258)\end{array}$ & $\begin{array}{l}-0.0485 \\
(0.261)\end{array}$ & -0.0172 \\
\hline wave2 & & $\begin{array}{l}0.158 * \ldots \\
(0.0247)\end{array}$ & $\begin{array}{l}0.0486^{*} \\
(0.0276)\end{array}$ & $\begin{array}{l}0.0574^{* x} \\
(0.0276)\end{array}$ & 0.1882 & & $\begin{array}{l}0.164^{* \cdots} \\
(0.0254)\end{array}$ & $\begin{array}{c}0.0349 \\
(0.0284)\end{array}$ & $\begin{array}{l}0.0480^{*} \\
(0.0285)\end{array}$ & 0.1543 \\
\hline Constant & $\begin{array}{c}6.468 \times \cdots \\
(0.197)\end{array}$ & $\begin{array}{c}7.792^{* * *} \\
(0.492)\end{array}$ & $\begin{array}{c}5.728^{* \ldots} \\
(0.571)\end{array}$ & $\begin{array}{c}6.320^{k \times x} \\
\langle 0.583\rangle\end{array}$ & & $\begin{array}{c}6.362^{* \ldots *} \\
(0.194)\end{array}$ & $\begin{array}{c}7.634^{\cdots *} \\
(0.506)\end{array}$ & $\begin{array}{c}4.952^{\cdots \cdots} \\
(0.591)\end{array}$ & $\begin{array}{c}5.508^{* * *} \\
(0.606)\end{array}$ & \\
\hline Country FE & & $\mathrm{x}$ & $\mathbf{x}$ & $x$ & $x$ & & $\mathbf{x}$ & $\mathbf{x}$ & $x$ & $x$ \\
\hline Observations & 18,400 & 18,400 & 15,027 & 14,221 & 14,221 & 17,349 & 17,349 & 14,375 & 13,468 & 13,468 \\
\hline R-squared & 0.029 & 0.126 & 0.120 & 0.124 & & 0.029 & 0.129 & 0.123 & 0.127 & \\
\hline
\end{tabular}

Robust standard errors in parentheses

$* 2 \times p<0.01, * * p<0.05, * p<0.1$

Note: Table shows OLS results for the sample of countries that joined the European Union after 2003, except for Latvia and Lithuania. 
Table 8: IV results - restricted sample without Latvia and Lithuania

\begin{tabular}{|c|c|c|c|c|}
\hline & (1) & (2) & (3) & (4) \\
\hline Dependent variable & $\begin{array}{l}\text { 1st stage } \\
\text { prood }\end{array}$ & $\begin{array}{l}\text { 2nd stage } \\
\text { redintribution }\end{array}$ & $\begin{array}{l}\text { Int stape } \\
\text { confeu }\end{array}$ & $\begin{array}{l}\text { Znd stage } \\
\text { redistributioe }\end{array}$ \\
\hline \multirow[t]{2}{*}{ joxineuts } & $-0.120 \cdots$ & & $0.122 * \cdots$ & \\
\hline & (0.0304) & & $\langle 0.0357\rangle$ & \\
\hline \multirow[t]{2}{*}{ pronad } & & $-15.490 * *$ & & \\
\hline & & $(3.734)$ & & \\
\hline \multirow[t]{2}{*}{ confeu } & & & & $16.17+\cdots$ \\
\hline & & & & $(5.009)$ \\
\hline \multirow[t]{2}{*}{ afe } & $-0,00 t 50$ & $-0.00 t 70$ & $-0.0167+\cdots$ & $0.297+\cdots$ \\
\hline & $(0.00234)$ & $(0,0373)$ & $\{0.00278\}$ & $(0.0504)$ \\
\hline \multirow[t]{2}{*}{$\operatorname{ag} 22$} & 7,7 se-05*n. & $0.00108=$ & $0.000162 \ldots$ & -0.000200. \\
\hline & (2:30e-05) & $(0.000466)$ & (2.7se-0s) & $(0.000032)$ \\
\hline \multirow[t]{2}{*}{ femake } & $0.03900 \cdots$ & $0.667 \cdots$ & $-0.0273^{*}$ & $0,465^{\circ}$ \\
\hline & $(0.0125)$ & $(0.254)$ & $(0.0146\rangle$ & $(0,281)$ \\
\hline \multirow[t]{2}{*}{ tecondary_incomplete } & $-0.0 \mathrm{t} 50$ & $-0.843^{2}$ & 0.0134 & - 0.758 \\
\hline & $(0.0221)$ & $(0.359)$ & $(0.0280\rangle)$ & $(0,408)$ \\
\hline \multirow[t]{2}{*}{ tecondary } & -0.0200 & $-0.919+\cdots$ & 0.00470 & .0 .514 \\
\hline & (0.0185) & $(0.301)$ & $\{0,0237\}$ & $(0.394)$ \\
\hline \multirow[t]{2}{*}{ Lertinty } & $-0.1003 * *$ & $-2.53 t \cdots \cdots$ & $0.0631 \%$ & $-1.805 * \cdots$ \\
\hline & $\{0.0221\}$ & (0.503) & $(0,0266)$ & $(0.526)$ \\
\hline \multirow[t]{2}{*}{ mattied } & $0.0462 * * *$ & $0.756 *$ & -0.00821 & 0.176 \\
\hline & $(0.0158)$ & $(0.297)$ & $\{0.0185\rangle$ & $(0.3 \pm 2)$ \\
\hline \multirow[t]{2}{*}{ Detsiliten } & -0.00513 & -0.291 & 0.0333 & $-0.740^{\circ}$ \\
\hline & $(0.0202)$ & $(0.319)$ & $(0,0239)$ & $(0.430)$ \\
\hline \multirow[t]{2}{*}{ iseutse } & $0.0102 * * *$ & 0.0812 & $0.03 .03 * 2$. & $-0.600 \%$ \\
\hline & (0.no320) & (0.0638) & $\{0.00381)$ & $(0.202)$ \\
\hline \multirow[t]{2}{*}{ uturmplogred } & $-0,084,6$ & $-1.154=0$ & $-0.0521 *$ & $0.935^{*}$ \\
\hline & (0.0257) & $(0.510)$ & $\{0.0288\}$ & (0.848) \\
\hline \multirow[t]{2}{*}{ townsine } & $+00250 \cdots$ & $-0.4200 \cdots$ & $0,0 x 13 *$. & $-0.200 \%$ \\
\hline & $(0.00268)$ & $(0.102)$ & $\{0.00511\}$ & $(0.0782)$ \\
\hline \multirow[t]{2}{*}{ wave } & $-0.3652 \cdots$ & $-2.908 \cdots$ & $0.255, \ldots$ & +1.244 \\
\hline & $(0.0786)$ & $(1: 231)$ & $(0.0561\rangle$ & $(1.356)$ \\
\hline \multirow[t]{2}{*}{ wave2 } & $0.03780+*$ & $0.299 \%$ & $0,0355 \ldots$ & $0.275^{\circ}$ \\
\hline & $(0.00875)$ & $(0.126)$ & $(0.0167)$ & $(0.157)$ \\
\hline \multirow[t]{2}{*}{ Constant } & $4.022 * \ldots$ & $62.13^{* * *}$ & 24700. & $-40,90 *$ \\
\hline & $(0.173)$ & (13.65) & $(0.214)$ & $(14.59)$ \\
\hline Country FE & $x$ & $x$ & $x$ & $x$ \\
\hline Oteervations & 14,221 & 14,221 & 13,465 & 13,468 \\
\hline B-equared & 0.090 & -13.758 & 0.048 & -20.602 \\
\hline \multicolumn{5}{|c|}{ Pobust standard errors in parentheses } \\
\hline \multicolumn{5}{|c|}{$\cdots_{p<0.01,} \cdots p<005, * p<0.1$} \\
\hline \multicolumn{5}{|c|}{ Test of excluded instruments } \\
\hline & \multicolumn{2}{|c|}{$P(1,14199)=17.91$} & \multicolumn{2}{|c|}{$F(t, 13446)=10.99$} \\
\hline & \multicolumn{2}{|c|}{ Prob $>\mathrm{P}=0.0000$} & Prob > & $?=0.0000$ \\
\hline Endngeneity uest of end & genous regress & xtsi & & \\
\hline & & .095 & & 756 \\
\hline & Chi-ma(1) I & $-\mathrm{val}-0.0000$ & Chi-mesiti) & $-\mathrm{vul}=0.0000$ \\
\hline
\end{tabular}

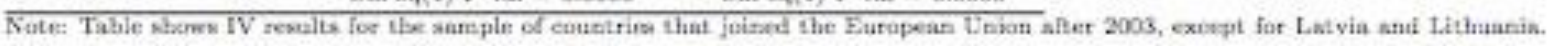




\section{References}

Akerlof G. A. 1997. Social distance and social decisions. Econometrica 65,1005-1027.

Akerlof G. A. and Kranton R. E. 2000. Economics and identity. The Quarterly Journal of Economics 115, 715-753.

Akerlof G. A. and Kranton R. E. 2005. Identity and the economics of organizations. Journal of Economic Perspectives 19, 9-32.

Alesina A., Glaeser E. and Sacerdote B. 2001. Why doesn't the United States have a European-style welfare state? Brookings Papers on Economic Activity (2), 1-70.

Asch S. E. 1951. Groups, Leadership and Men, Chapter Effects of group pressure upon modification and distortion of judgement. Carnegie Press.

Battu H. and Zenou Y. 2010. Oppositional identities and employment for ethnic minorities: Evidence from England. The Economic Journal 120, 52 _ 71.

Benabou R. and Ok E. 2001. Social mobility and the demand for redistribution: The POUM hypothesis. Quarterly Journal of Economics 116, 447_487.

Bowles S. 1998. Endogenous preferences: The cultural consequences of markets and other economic institutions. Journal of Economic Literature 36, 75_111.

Carey S. 2002. Undivided loyalties: Is national identity an obstacle to European integration? European Union Politics 3, 387_413.

Carlsson F., Johansson-Stenman O. and Khanh Nam P. 2014. Social preferences are stable over long periods of time. Journal of Public Economics 117, 104-114.

Casella A. and Frey B. 1992. Federalism and clubs. towards an economic theory of overlapping political jurisdictions. European Economic Review 36, 635-646.

Charness G., Rigotti L., and Rustichini A. 2007. Individual behavior and group membership. American Economic Review 97, 1340-1352.

Chen Y. and Li S. X. 2009. Group identity and social preferences. The American Economic Review 99, 431-457.

Corneo G. and Grüner H.P. 2002. Individual preferences for political redistribution. Journal of Public Economics 83, 83-107.

Costa-Font J. and Cowell F. A. (2015). Social identity and redistributive preferences. Journal of Economic Surveys 29, 357-374.

Cremer D. D. and Vugt M. V. 1999. Social identification effects in social dilemmas: A transformation of motives. European Journal of Social Psychology 29, 871-893.

Cruces G., Perez-Trugliad R. and Tetaz M. 2013. Biased perceptions of income distribution and preferences for redistribution. Journal of Public Economics 98, 100- 112.

Durante R., Putterman L. and van der Weele J. 2014. Preferences for redistribution and perception of fairness: An experimental study. Journal of the European Economic Association 12, 1059-1086.

Lindqvist, E. and Östling R. 2013. Identity and redistribution. Public Choice 155, 469-491. 
Lowes, S., Nunn N., Robinson J., and Weigel J. 2015. Understanding ethnic identity in Africa: Evidence form the implicit association test (iat). Working Paper 20885, NBER.

Luttmer E., Singhal F. and M. 2011. Culture, context and taste for redistribution. American Economic Journal: Economic Policy 3, 157-179.

Luttmer, E. F. P. 2001. Group loyalty and the taste for redistribution. Journal of Political Economy 199, 500-528.

Mayer, F. and Palmowski J. 2004. European identities and the EU - the ties that bind peoples of Europe. Journal of Common Market Studies 42, 573-598.

Meltzer, A. H. and Richard S. F. 1981. A rational theory of the size of government. Journal of Political Economy 89, 914-927.

Norton, M. and Ariely D. 2011. Building better America - one wealth quintile at a time.

Perspectives on Psychological Science 6, 9-12.

Risse, T. 2010. A Community of Europeans? Transnational Identities and Public Spheres. Ithaca, NY: Cornell University Press.

Roccas, S. 2003. The effects of status on identification with multiple groups. European Journal of Social Psychology 33, 351-366.

Romer, T. 1975. Individual welfare, majority voting, and the properties of a linear income tax. Journal of Public Economics 4, 163-185.

Shayo, M. 2009. A model of social identity with an application to political economy: Nation, class, and redistribution. American Political Science Review 103, 147-174.

Tajfel, H. 1978. Differentiation between social groups: Studies in the psychology of intergroup relations. Academic Press.

Transue, J. E. 2007. Identity salience, identity acceptance and racial political attitude: American national identity as uniting force. American Journal of Political Science 51, 78-91.

Zakharov, A. and E. Ponarin 2013. Genetic factors and preferences for redistribution.

Technical report, Mimeo,

http://www.lisbonmeeting.org.pt/wpcontent/uploads/2013/05/redist-ribution.pdf. 


\section{Appendix A.1 - Data}

\section{A.1.1 Summary characteristics}

\section{A.1.1 Summary characteristics}

\begin{tabular}{|c|c|c|c|c|}
\hline Country - year & $N$ & Size of town & $N$ & $\%$ \\
\hline Bulgaria (1997) & 1072 & 2,000 and less & 6124 & 25.69 \\
\hline Bulgaria (2005) & 1001 & $2,000-5,000$ & 3570 & 14.98 \\
\hline Croatia (1996) & 1196 & $5,000-10,000$ & 1816 & 7.62 \\
\hline Cyprus (2006) & 1050 & $10,000-20,000$ & 1825 & 7.66 \\
\hline Cyprus (2011) & 1000 & $20,000-50,000$ & 2386 & 10.01 \\
\hline Czech Republic (1991) & 924 & $50,000-100,000$ & 1657 & 6.95 \\
\hline Estonia (1996) & 1021 & $100,000-500,000$ & 4234 & 17.76 \\
\hline Estonia (2011) & 1533 & 500,000 and more & 2226 & 9.34 \\
\hline Hungary (1982) & 1464 & Total & 23838 & 100 \\
\hline Hungary (1998) & 650 & & & \\
\hline Hungary (2009) & 1007 & & & \\
\hline Latvia (1996) & 1200 & & & \\
\hline Lithuania (1997) & 1009 & Sex & $N$ & $\%$ \\
\hline Poland (1989) & 938 & Male & 12731 & 46.54 \\
\hline Poland (1997) & 1153 & Female & 14623 & 53.46 \\
\hline Poland (2005) & 1000 & Total & 27354 & 100 \\
\hline Poland (2012) & 966 & & & \\
\hline Romania (1998) & 1239 & & & \\
\hline Romania (2005) & 1776 & Age & $N$ & $\%$ \\
\hline Romania (2012) & 1503 & 15 to 24 & 3448 & 12.59 \\
\hline Slovakia $(1990)$ & 466 & 25 to 34 & 4694 & 17.15 \\
\hline Slovakia (1998) & 1095 & 35 to 44 & 4878 & 17.82 \\
\hline Slovenia (1995) & 1007 & 45 to 54 & 4539 & 16.58 \\
\hline Slovenia $(2005)$ & 1037 & 55 to 64 & 4109 & 15.01 \\
\hline Slovenia (2011) & 1069 & 65 and over & 5708 & 20.85 \\
\hline Total & 27376 & Total & 27376 & 100 \\
\hline
\end{tabular}




\begin{tabular}{|c|c|c|c|c|c|}
\hline Highest educational level attained & $N$ & $\%$ & Employment status & $N$ & $\%$ \\
\hline Incomplete elementary & 1306 & 5.91 & Full time & 11712 & 44.94 \\
\hline Compulsory elementary education & 3078 & 13.92 & Part time & 1001 & 3.84 \\
\hline Incomplete secondary : technical/vocational & 1898 & 8.58 & Self employed & 1210 & 4.64 \\
\hline Complete secondary : technical/vocational & 5473 & 24.75 & Retired & 6716 & 25.77 \\
\hline Incomplete secondary: university-prep & 1382 & 6.25 & Housewife & 1731 & 6.64 \\
\hline Complete secondary: university-prepa & 4030 & 18.23 & Students & 1407 & 5.40 \\
\hline University without degree & 1453 & 6.57 & Unemployed & 1882 & 7.22 \\
\hline University with degree & 3491 & 15.79 & Other & 402 & 1.54 \\
\hline Total & 22111 & 100 & Total & 26061 & 100 \\
\hline Self positioning in political scale & $N$ & $\%$ & Income scale & $N$ & $\%$ \\
\hline Left & 1132 & 5.65 & Lowest step & 2238 & 9.67 \\
\hline 2 & 765 & 3.82 & Second step & 2421 & 10.46 \\
\hline 3 & 1461 & 7.29 & Third step & 2924 & 12.64 \\
\hline 4 & 1583 & 7.9 & Fourth step & 3275 & 14.15 \\
\hline 5 & 6834 & 34.11 & Fifth step & 4342 & 18.76 \\
\hline 6 & 2869 & 14.32 & Sixth step & 2870 & 12.40 \\
\hline 7 & 1778 & 8.87 & Seventh step & 2210 & 9.55 \\
\hline 8 & 1619 & 8.08 & Eighth step & 1450 & 6.27 \\
\hline 9 & 711 & 3.55 & Ninth step & 825 & 3.57 \\
\hline Right & 1284 & 6.41 & Tenth step & 585 & 2.53 \\
\hline Total & 20036 & 100 & Total & 23140 & 100 \\
\hline
\end{tabular}

Source:"Citizenship education in Europe"

Available data (all for 2010/2011):

\section{A 1.2 Background information: Citizenship education}

- Provision of a separate, compulsory subject focused on elements of citizenship education, according to national curricula (ISCED ${ }^{17} 1,2$ and 3 ), 2010/11.

- Citizenship education taught as a separate subject or integrated into other subjects, by ages, according to national curricula, 2010/11.

- subject during a notional year, based on the recommendations for primary, general (lower and upper) secondary education, 2010/11.

- Average minimum taught time devoted to citizenship education as a separate

Some information on the concept of citizenship education: "The civic competences needed to be able to actively exercise citizenship, as defined by the European framework for key competences, focus on: a knowledge of basic democratic concepts including an understanding of society and social and political movements; the European integration process and EU structures; and major social developments, both past and present.

\footnotetext{
17 International Standard Classification of Education http://www.uis.unesco.org/Education/Pages/internationalstandard-classification-of- education.aspx
} 
Civic competences also require skills such as critical thinking and communication skills, and the ability and willingness to participate constructively in the public domain, including in the decision-making process through voting. Finally, a sense of belonging to society at various levels, a respect for democratic values and diversity as well as support for sustainable development are also highlighted as integral components of civic competences. In the context of this report, citizenship education refers to the aspects of education at school level intended to prepare students to become active citizens, by ensuring that they have the necessary knowledge, skills and attitudes to contribute to the development and well-being of the society in which they live. It is a broad concept, which encompasses not only teaching and learning in the classroom but also practical experiences gained through school life and activities in wider society. It encompasses the narrower concept of â $\epsilon^{\sim}$ civic education', as defined by the IEA, ${ }^{18}$ which is restricted to 'knowledge and understanding of formal institutions and processes of civic life (such as voting in elections)" (IEA 2010a, p. 22).

2004/05: Age at which pupils are taught citizenship education as a separate compulsory subject and duration of this provision in primary and general secondary education.

2010/11: Citizenship education taught as a separate subject or integrated into other subjects, by ages, according to national curricula.

\section{A 1.3 Background information: Foreign language proficiency}

a) Source: "Recommended annual instruction time in full-time compulsory education in Europe 2013/14".

Available data:

- Number of hours and grades attained by school year for foreign languages 1 for 9 out of 12 countries.

- Number of hours and grades attained for by school year for foreign languages 2 for 6 out of 12 countries.

b) Source: "Key data on teaching languages at school in Europe 2012"

Note: In this publication, there are also trends available in different years; however, the changes are usually none or small.

Available data:

- Starting ages for the first and second foreign languages as compulsory subjects for all students in pre-primary, primary and/or general secondary education, 
18 International Association for the Evaluation of Educational Achievement-http://www.iea.nl/

- 2010/11.

- Starting age and duration of first foreign language as a compulsory subject in pre-primary, primary and/or general secondary education, reference years 1993/94, 2002/03, 2006/07, 2010/11.

- Starting age and duration of second foreign language as a compulsory subject in pre-primary, primary and/or general secondary education, 2002/03, 2006/07, 2010/11.

- Provision of foreign languages as core curriculum options in primary and/or general secondary level, 2010/11.

- Percentage of students learning 0,1,2 or more language(s) in general upper secondary education (ISCED 3), 2004/05, 2006/07, 2009/10.

- Trends in the percentage of students learning English, German and French in lower secondary education (ISCED 2), in 2004/05, 2006/07, 2009/10.

- Trends in the recommended minimum number of hours of compulsory foreign language teaching during a notional year in primary and full- time compulsory general secondary education, 2006/07 and 2010/11.

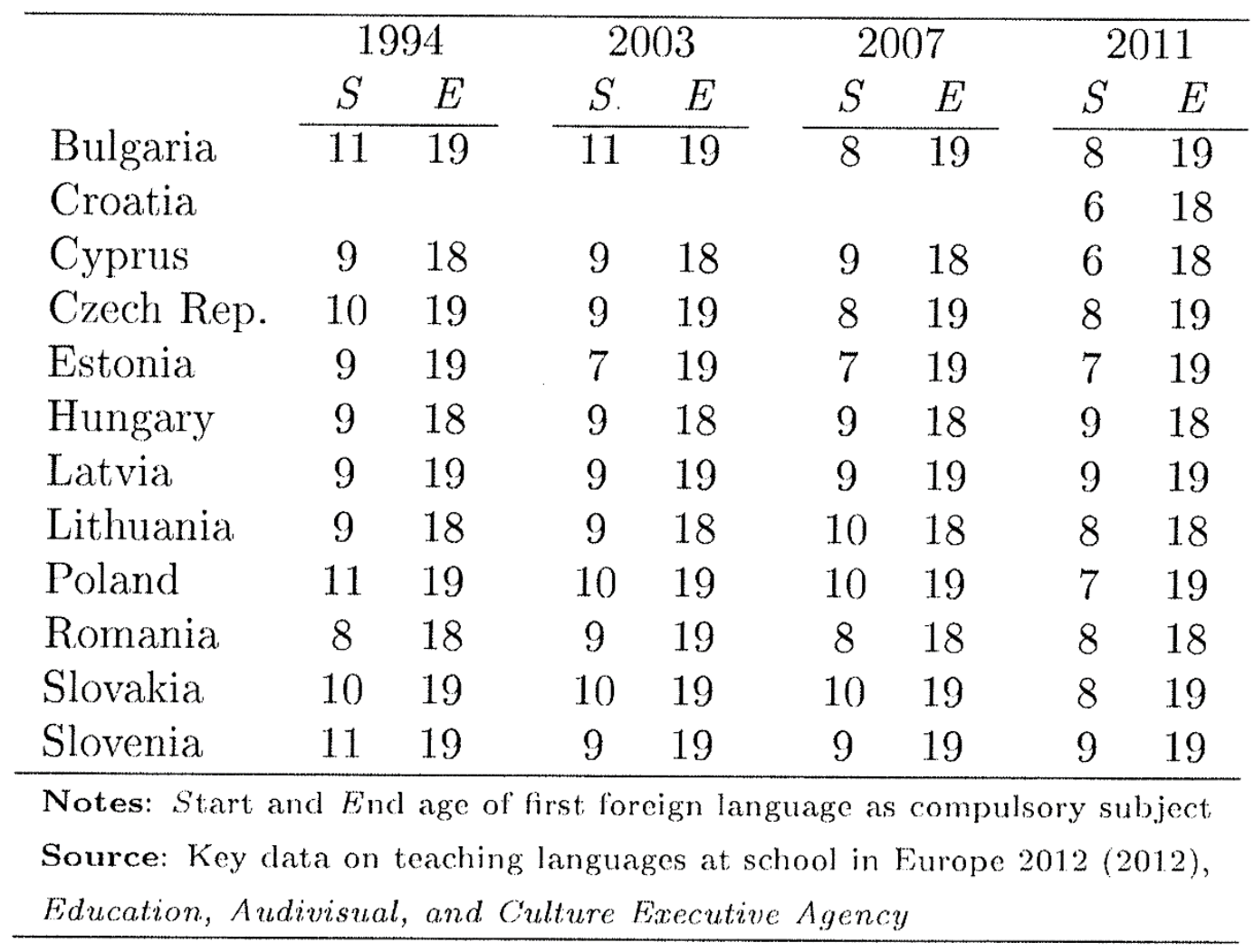




\section{A 1.4 Background information: Medals in Olympic Games}

A.1.4 Background information: Medals in Olympic Games

\begin{tabular}{|c|c|c|c|c|c|c|c|c|c|c|c|c|c|c|}
\hline & $\begin{array}{l}\overrightarrow{0} \\
\stackrel{8}{9}\end{array}$ & $\begin{array}{l}\infty \\
\infty \\
0 \\
- \\
-1\end{array}$ & 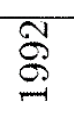 & 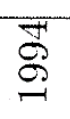 & 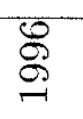 & $\begin{array}{l}\infty \\
\stackrel{2}{\Omega}\end{array}$ & §్̊ి & $\stackrel{\widetilde{N}}{\tilde{N}}$ & 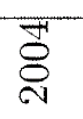 & 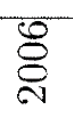 & $\begin{array}{l}\infty \\
\stackrel{\sim}{0}\end{array}$ & 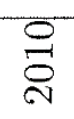 & $\underset{\vec{\Xi}}{\tilde{\Xi}}$ & $\vec{\sim}$ \\
\hline Bulgaria & 0 & 35 & 16 & 0 & 15 & 1 & 13 & 3 & 12 & 1 & 5 & 0 & 2 & 0 \\
\hline Croatia & 0 & 0 & 3 & 0 & 2 & 0 & 2 & 4 & 5 & 3 & 5 & 3 & 6 & 1 \\
\hline Cyprus & 0 & 0 & 0 & 0 & 0 & 0 & 0 & 0 & 0 & 0 & 0 & 0 & 1 & 0 \\
\hline Czech Rep. & & & & 0 & 11 & 3 & 8 & 3 & 8 & 4 & 6 & 6 & 10 & 8 \\
\hline Estonia & & & 2 & 0 & 0 & 0 & 3 & 3 & 3 & 3 & 2 & 1 & 2 & 0 \\
\hline Hungary & 0 & 23 & 30 & 0 & 21 & 0 & 17 & 0 & 17 & 0 & 10 & 0 & 18 & 0 \\
\hline Latvia & & & 3 & 0 & 1 & 0 & 3 & 0 & 4 & 1 & 3 & 2 & 2 & 4 \\
\hline Lithuania & & & 2 & 0 & 1 & 0 & 5 & 0 & 3 & 0 & 5 & 0 & 5 & 0 \\
\hline Poland & 0 & 16 & 19 & 0 & 17 & 0 & 14 & 2 & 10 & 2 & 10 & 6 & 10 & 6 \\
\hline Romania & 53 & 24 & 18 & 0 & 20 & 0 & 26 & 0 & 19 & 0 & 8 & 0 & 9 & 0 \\
\hline Slovakia & & & & 0 & 3 & 0 & 5 & 0 & 6 & 1 & 6 & 3 & 4 & 1 \\
\hline Slovenia & & & 2 & 3 & 2 & 0 & 2 & 1 & 4 & 0 & 5 & 3 & 4 & 8 \\
\hline
\end{tabular}




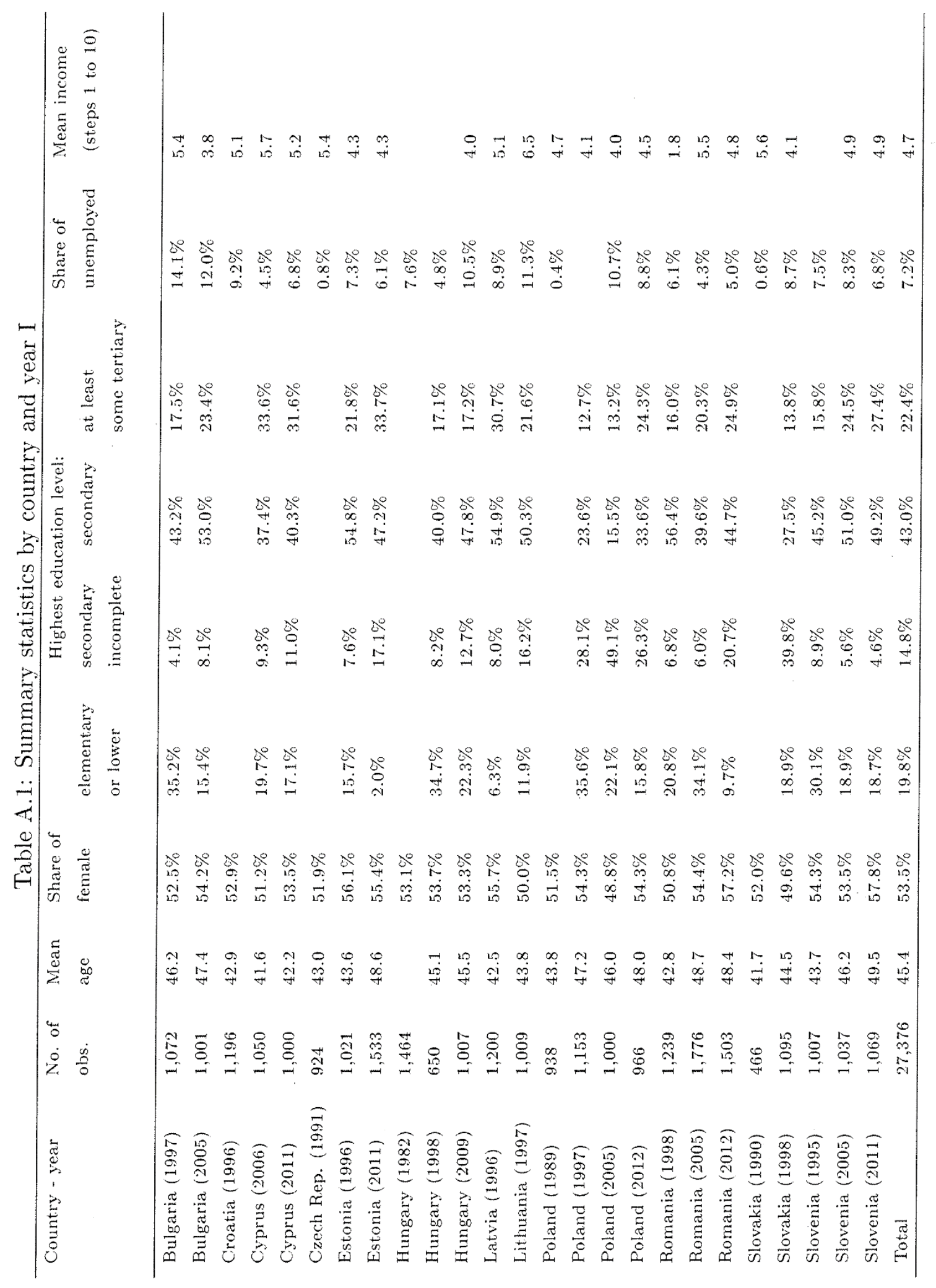

\section{A.2 Summary statistics of sample}


Table A.2: Summary statistics by country and year II

\begin{tabular}{|c|c|c|c|c|c|}
\hline Country - year & $\begin{array}{l}\text { Mean } \\
\text { political } \\
\text { oricntation } \\
(1 \text {-left, } \\
10 \text {-right })\end{array}$ & $\begin{array}{l}\text { Share of } \\
\text { respondents } \\
\text { with } \\
\text { children }\end{array}$ & $\begin{array}{l}\text { Mean redis- } \\
\text { tribution } \\
(1 \text {-need } \\
\text { larger } \\
\text { income } \\
\text { diff's, } \\
10 \text {-incomes } \\
\text { shd be } \\
\text { made more } \\
\text { equal) }\end{array}$ & $\begin{array}{l}\text { Mean proud } \\
\text { of } \\
\text { nationality } \\
(1=\text { not at } \\
\text { all, } 2 \text {-not } \\
\text { very, } \\
3 \text {-quite, } \\
4 \text {-very })\end{array}$ & $\begin{array}{l}\text { Mean } \\
\text { confidence } \\
\text { in the EU } \\
(1-\text { none at } \\
\text { all, } 2-\text {-not } \\
\text { very much, } \\
3 \text {-quite a } \\
\text { lot, } 4=\text {-a } \\
\text { great deal })\end{array}$ \\
\hline Bulgaria (1997) & 5.8 & $81.1 \%$ & 5.6 & 3.3 & 2.9 \\
\hline Bulgaria (2005) & 4.8 & $82.9 \%$ & 5.3 & 3.2 & 2.6 \\
\hline Croatia (1996) & 5.2 & $72.0 \%$ & 6.0 & 3.2 & 2.2 \\
\hline Cyprus (2006) & 5.2 & $68.6 \%$ & 5.7 & 3.4 & 2.4 \\
\hline Cyprus (2011) & 5.2 & $59.4 \%$ & 7.5 & 3.4 & 2.5 \\
\hline Czech Republic (1991) & 5.7 & $83.1 \%$ & 2.9 & 2.8 & \\
\hline Estonia (1996) & 5.4 & $80.1 \%$ & 5.5 & 2.9 & 2.7 \\
\hline Estonia (2011) & 5.4 & $74.9 \%$ & 7.2 & 2.9 & 2.5 \\
\hline Hungary (1982) & & $74.9 \%$ & & 3.6 & \\
\hline Hungary (1998) & 5.1 & $74.3 \%$ & 7.2 & 3.4 & 2.7 \\
\hline Hungary (2009) & 5.7 & $70.8 \%$ & 6.4 & 3.3 & 2.5 \\
\hline Latvia (1996) & 5.4 & $71.2 \%$ & 4.5 & 2.8 & 2.6 \\
\hline Lithuania (1997) & 5.8 & $77.7 \%$ & 5.8 & 2.8 & 2.5 \\
\hline Poland (1989) & 5.8 & & 3.1 & 3.7 & \\
\hline Poland (1997) & 5.7 & $78.0 \%$ & 4.3 & 3.7 & 2.6 \\
\hline Poland (2005) & 5.9 & $70.4 \%$ & 4.2 & 3.6 & 2.4 \\
\hline Poland (2012) & 5.5 & $73.4 \%$ & 4.7 & 3.6 & 2.3 \\
\hline Romania (1998) & 5.3 & $72.3 \%$ & 4.7 & 3.3 & 2.5 \\
\hline Romania (2005) & 6.0 & $79.5 \%$ & 6.3 & 3.2 & 2.6 \\
\hline Romania (2012) & 5.6 & $76.6 \%$ & 4.9 & 3.3 & 2.4 \\
\hline Slovakia (1990) & 5.4 & $74.4 \%$ & 4.3 & 3.0 & \\
\hline Slovakia (1998) & 5.3 & $79.8 \%$ & 5.4 & 3.3 & 2.5 \\
\hline Slovenia (1995) & 5.2 & $72.6 \%$ & 6.5 & 3.5 & 2.4 \\
\hline Slovenia (2005) & 5.3 & $71.4 \%$ & 6.3 & 3.5 & 2.3 \\
\hline Slovenia (2011) & 5.1 & $74.5 \%$ & 7.5 & 3.4 & 2.1 \\
\hline Total & 5.5 & $74.9 \%$ & 5.6 & 3.3 & 2.5 \\
\hline
\end{tabular}


Table A.3: Summary statistics: survey waves

\begin{tabular}{lll}
\hline Wave & Freq. & Percent \\
\hline $1981-1984$ & 1,464 & 5.35 \\
$1989-1993$ & 2,328 & 8.5 \\
$1994-1998$ & 10,642 & 38.87 \\
$2005-2009$ & 6,871 & 25.1 \\
$2010-2014$ & 6,071 & 22.18 \\
Total & 27,376 & 100 \\
\hline
\end{tabular}

Table A.4: Summary statistics: attitudes towards redistribution

\begin{tabular}{llll}
\hline Income equality (redistribution) & Freq. & Percent & Cum. \\
\hline 1 (Need larger income diff's) & 3,126 & 12.4 & 12.4 \\
2 & 1,567 & 6.21 & 18.61 \\
3 & 3,116 & 12.36 & 30.97 \\
4 & 2,447 & 9.7 & 40.67 \\
5 & 1,913 & 7.59 & 48.26 \\
6 & 3,108 & 12.33 & 60.58 \\
7 & 2,041 & 8.09 & 68.68 \\
8 & 2,491 & 9.88 & 78.56 \\
9 & 1,729 & 6.86 & 85.41 \\
10 (Incomes shd be made more equal) & 3,678 & 14.59 & 100 \\
Total & 25,216 & 100 & \\
\hline
\end{tabular}

Table A.5: Summary statistics: national pride

\begin{tabular}{llll}
\hline How proud of nationality & Freq. & Percent & Cum. \\
\hline Not at all & 763 & 2.93 & 2.93 \\
Not very & 3,131 & 12.03 & 14.96 \\
Quite & 10,153 & 39.01 & 53.98 \\
Very & 11,978 & 46.02 & 100 \\
Total & 26,025 & 100 & \\
\hline
\end{tabular}

Table A.6: Summary statistics: confidence in the EU

\begin{tabular}{llll}
\hline Confidence: the European Union & Freq. & Percent & Cum. \\
\hline None at all & 2,789 & 13.41 & 13.41 \\
Not very much & 7,342 & 35.31 & 48.72 \\
Quite a lot & 8,667 & 41.68 & 90.4 \\
A great deal & 1,997 & 9.6 & 100 \\
Total & 20,795 & 100 & \\
\hline
\end{tabular}


Table A.7: Summary statistics: adoption of euro

\begin{tabular}{llll}
\hline Country has adopted euro currency & Freq. & Percent & Cum. \\
\hline No & 23,774 & 86.84 & 86.84 \\
Yes & 3,602 & 13.16 & 100 \\
Total & 27,376 & 100 & \\
\hline
\end{tabular}

\section{A.3 Trends in preference and identity variables}

Figures A.1 to A.6 depict the trends in key variables across interview years and across survey waves for those countries that joined the European Union before 2004 and those countries that joined the EU between 2004 and 2013.

Figure A.3: National pride across interview years

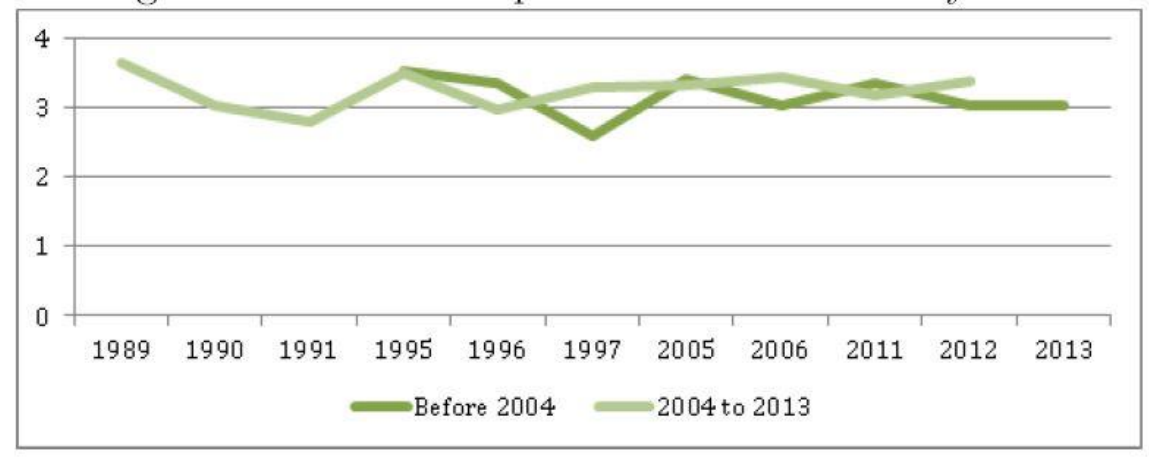

Source: World Values Survey (European Sample), 2014

Figure A.4: National pride across survey waves

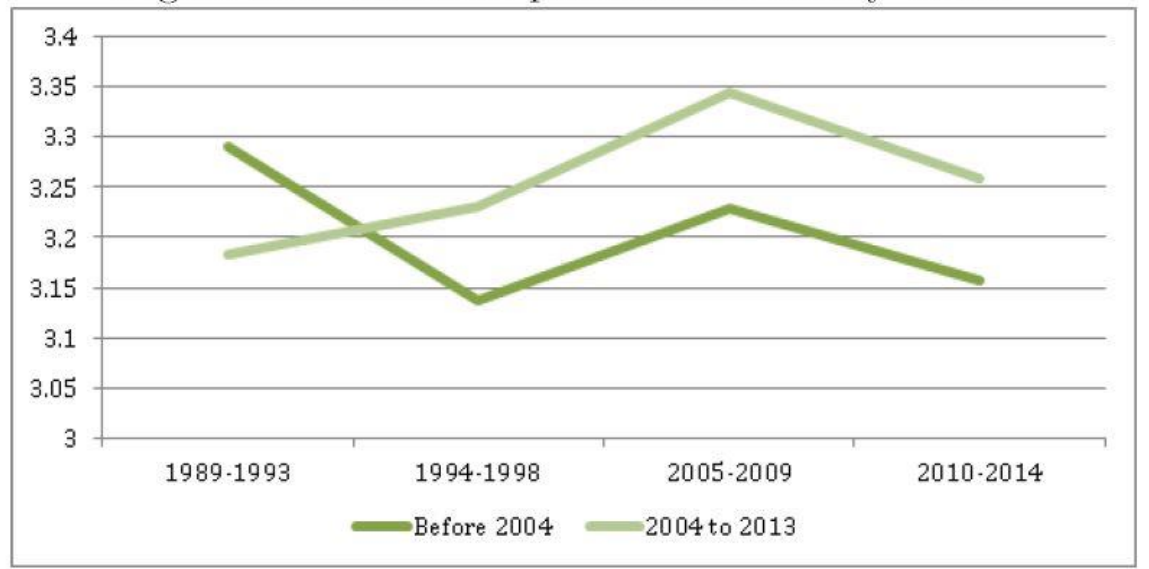

Source: World Values Survey (European Sample), 2014 


\section{A.4 Regressions: further analysis}

Tables A.8 to A.10 show the subsample analysis for different age, income and gender groups, respectively. Table A.11 shows the 1 st and 2 nd stage of instrumental variables regression for alternative main regressors. Columns (1) and (2) show citizencountry ("I see myself as a citizen of the [country] nation", with answers on a scale from 1 (strongly disagree) to 4 (strongly agree)); columns (3) and (4) show citizeneu ("I see myself as a citizen of the European Union", with answers on a scale from 1 (strongly disagree) to 4 (strongly agree)); columns (5) and (6) show the binary variable eu_notcountry taking a value of 1 if respondent agrees or strongly agrees to the statement "I see myself as a citizen of the EU" and disagrees or strongly disagrees with the statement "I see myself as a citizen of the [country] nation", and 0 otherwise; columns (7) and (8) show the binary variable country_noteu taking a value of 1 if respondent agrees or strongly agrees to the statement "I see myself as a citizen of the [country] nation" and disagrees or strongly disagrees with the statement "I see myself as a citizen of the EU", and 0 otherwise; columns (9) and (10) show the binary variable country_and_eu taking a value of 1 if respondent agrees or strongly agrees to both the statements "I see myself as a citizen of the [country] nation" and "I see myself as a citizen of the EU", and 0 otherwise. The dependent variable redistribution takes values from 1 (we need larger income differences as incentives for individual effort) to 10 (incomes should be made more equal); independent variables included are age, age squared, female, secondary incomplete, secondary, tertiary, married, children, income, unemployed, town size, wave, and wave squared.

Table A.12 investigates cohort effects; cohort_euro is a dummy variable taking the value of 1 if the euro was introduced during the age 16 to 25 (impressionable years); proud_cohort is national pride interacted with cohort_euro; joineuro_cohort is joineuro interacted with cohort_euro. Column(1) shows an OLS regression, columns (2) and (3) show the 1st and 2nd stage of an instrumental variables regression, with joineuro_cohort as an instrument for proud_cohort in the 2nd stage (column (3)). The dependent variable redistribution takes values from 1 (we need larger income differences as incentives for individual effort) to 10 (incomes should be made more equal). Independent variables included are age, age squared, female, secondary incomplete, secondary,tertiary, married, children, income, unemployed, town size, wave, and wave squared.

Table A.13 shows the interaction of national pride with income; proud income is national pride interacted with the income variable and joineuro income is the interaction of the variables joineuro and income. Column (1) shows an OLS regression, columns (2) and (3) show the 1st and 2nd stage of an instrumental 
variables regression with national pride instrumented with joineuro; columns (4) and (5) show proud_income instrumented with joineuro_income. The dependent variable redistribution takes values from 1 (we need larger income differences as incentives for individual effort) to 10 (incomes should be made more equal). Independent variables included are age, age squared, female, secondary incomplete, secondary, tertiary, married, children, income, unemployed, town size, wave, and wave squared.

Table A.14 shows the 1st and 2nd stage of instrumental variables regression for alternative instruments; columns (1) to (4) use duration of the first foreign language (in years) in compulsory schooling for each country/year; columns

(5) to (8) use the first component of a principal components analysis consisting of the variables duration of first foreign language, duration of citizenship education as a separate subject, and number of medals in Olympic

summer games. The dependent variable redistribution takes values from 1 (we need larger income differences as incentives for individual effort) to 10 (incomes should be made more equal); independent variables included are age, age squared, female, secondary incomplete, secondary, tertiary, married, children, income, unemployed, town size, wave, and wave squared.

Table A.15 shows the OLS regressions and Table 18 shows the 1st and 2nd stage of an instrumental variables regressions, for the full sample of European countries, not only those that joined the European Union after 2003. The countries/years included are Bulgaria (1997), Bulgaria (2005), Cyprus (2006), Cyprus (2011), Estonia (1996), Estonia (2011), Finland (1996), Finland (2005), France (2006), Germany (1997), Germany (2006), Germany (2013), Hungary (1998), Hungary (2009), Italy (2005), Latvia (1996), Lithuania (1997), Netherlands (2006), Netherlands (2012), Poland (1997), Poland (2005), Poland (2012), Romania (1998), Romania (2005), Romania (2012), Slovakia (1998), Slovenia (1995), Slovenia (2005), Slovenia (2011), Spain (1995), Spain (2000),Spain (2007), Spain (2011), Sweden (1996), Sweden (2006), Sweden (2011) and Great Britain (2005). 


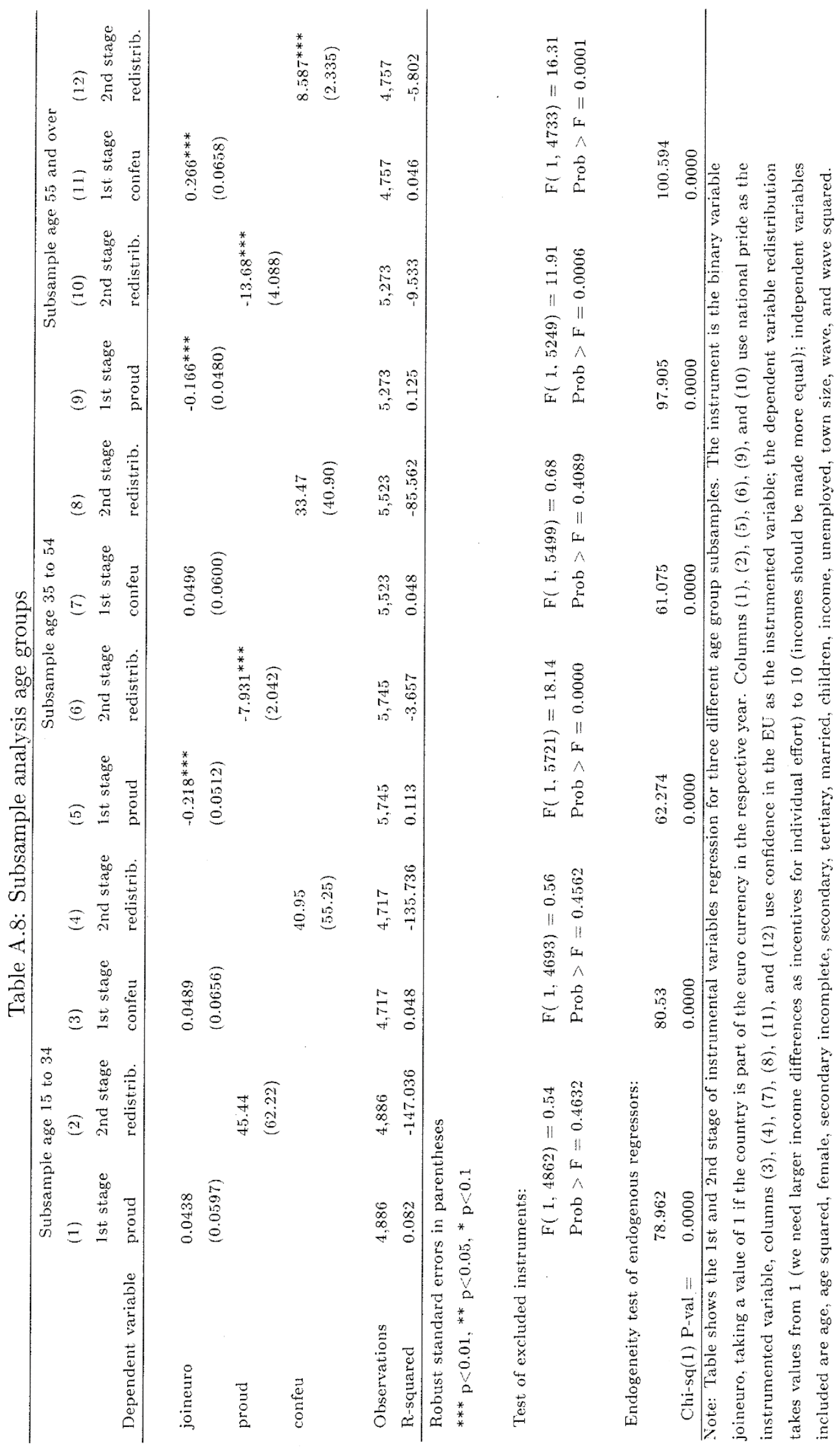




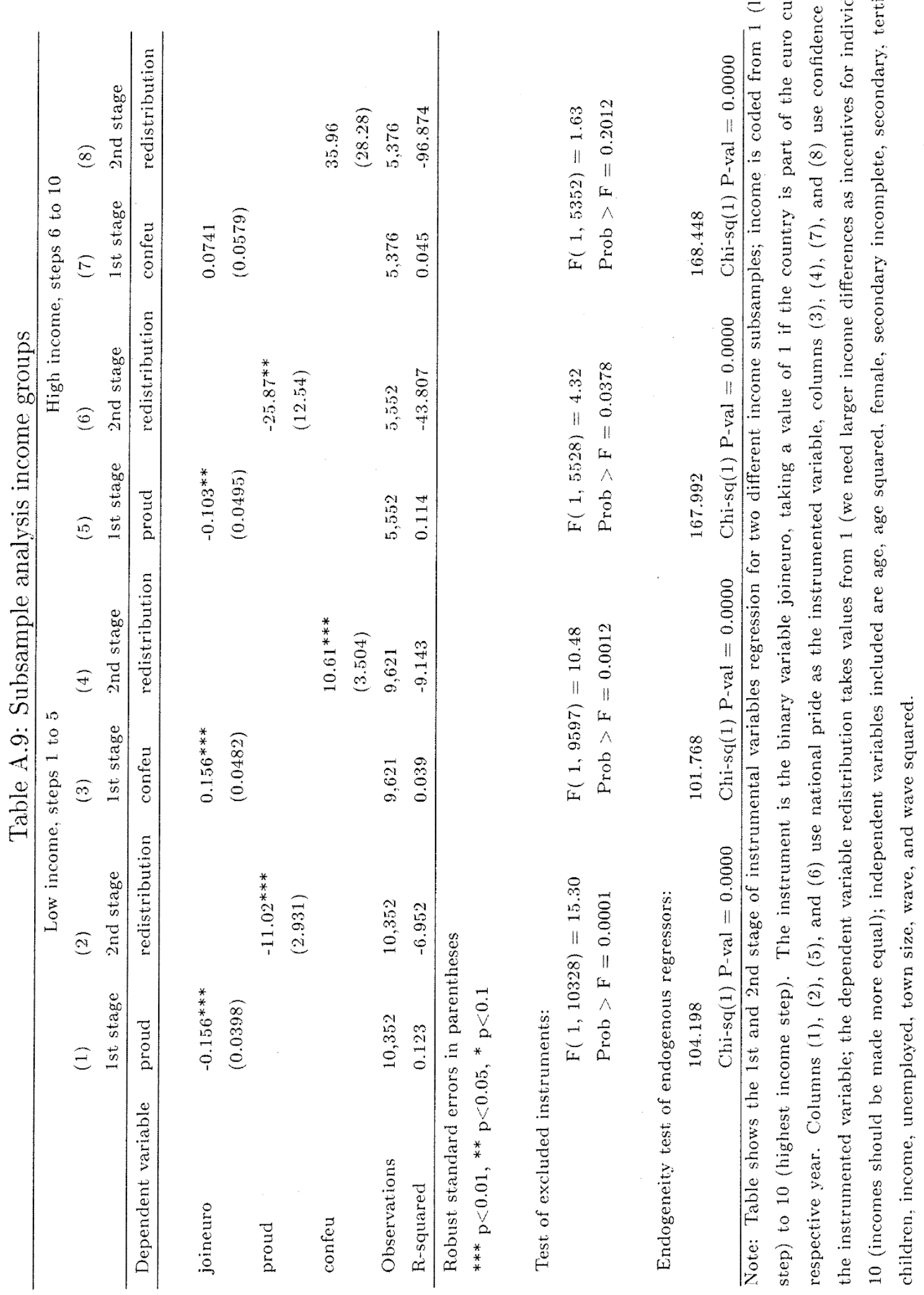




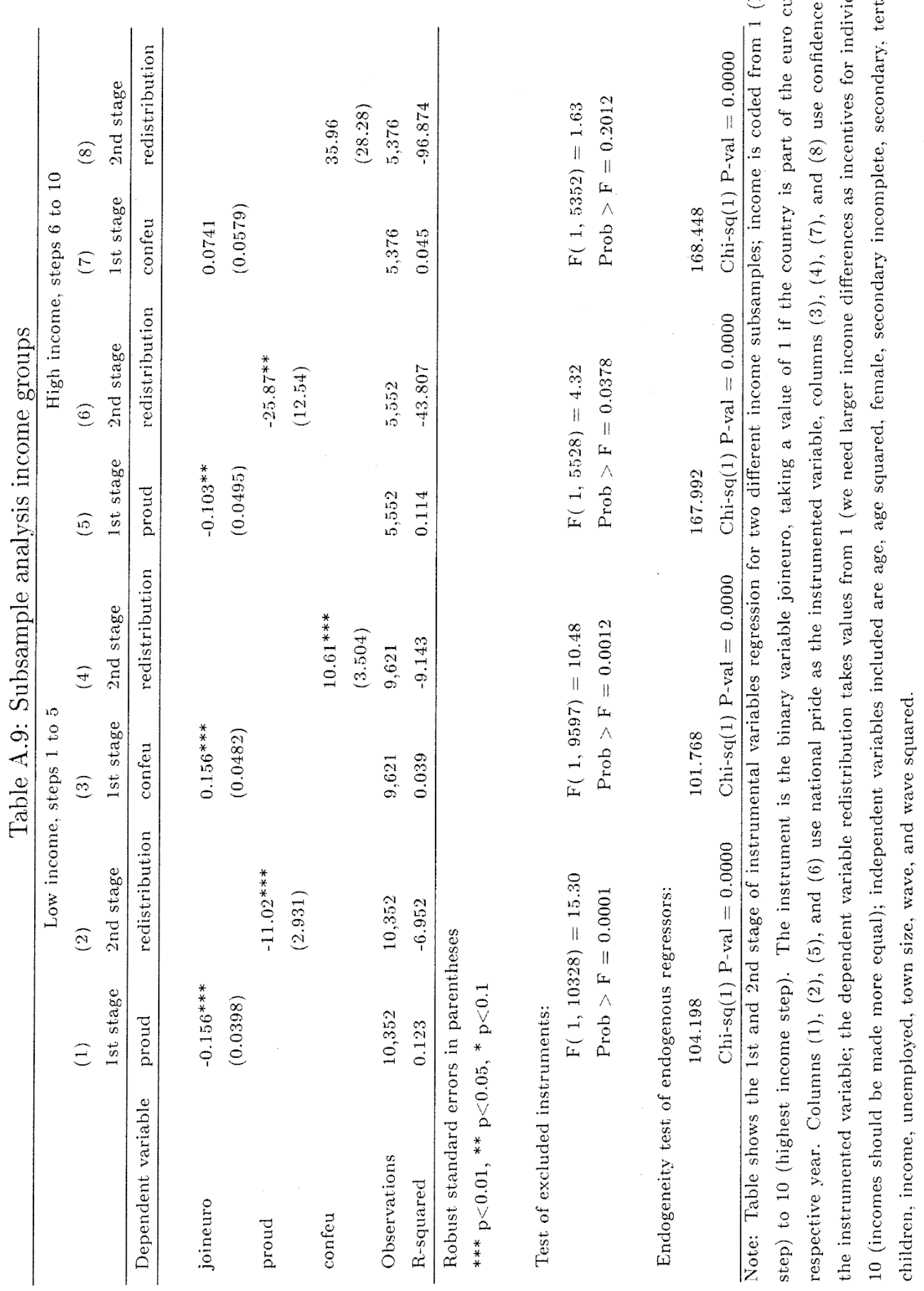


Table A.11: Additional main regressors

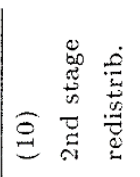

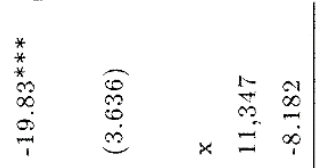

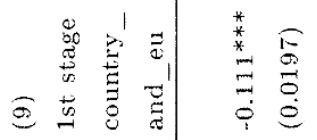

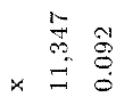

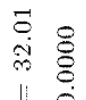
今
$\Rightarrow \hat{0}$

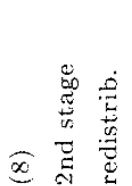
方

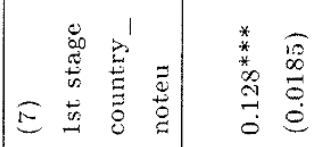

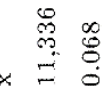

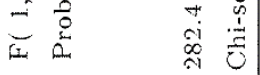
包若

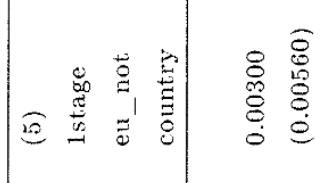

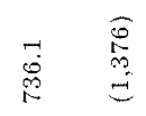

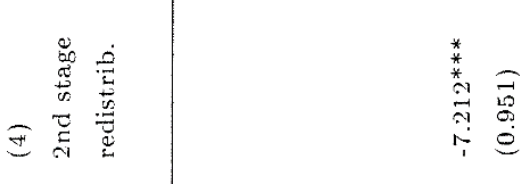

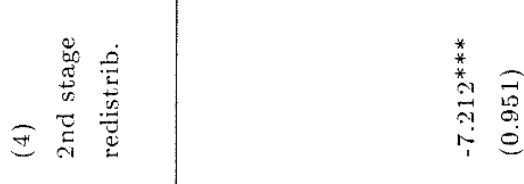
蒿

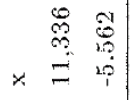

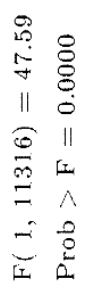

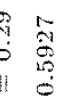

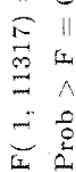

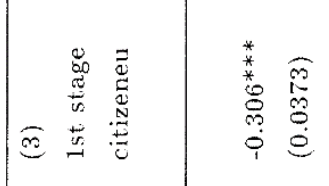

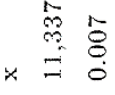

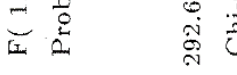

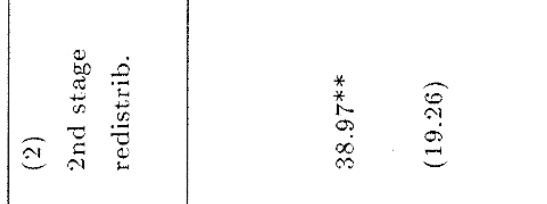

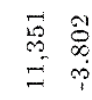

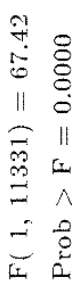

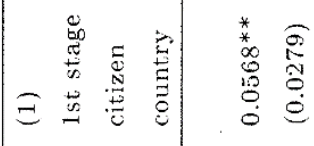

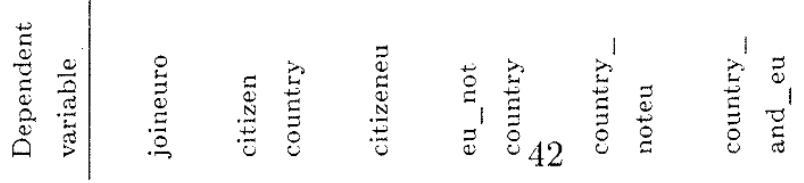


Table A.12: Cohort effects

\begin{tabular}{|c|c|c|c|}
\hline \multirow[b]{3}{*}{ Dependent variable } & \multirow{3}{*}{$\begin{array}{l}\text { (1) } \\
\text { redistribution }\end{array}$} & \multicolumn{2}{|c|}{$\begin{array}{c}\text { IV: proud_cohort instrumented } \\
\text { with joineuro_cohort }\end{array}$} \\
\hline & & (2) & (3) \\
\hline & & proud_cohort & redistribution \\
\hline \multirow[t]{2}{*}{ proud } & $-0.258 * * *$ & $0.0521 * * *$ & 1.074 \\
\hline & $(0.0306)$ & $(0.00333)$ & $(2.173)$ \\
\hline \multirow{2}{*}{ cohort_euro } & 0.148 & $3.220 * * *$ & 82 \\
\hline & $(0.422)$ & $(0.0501)$ & $(132.6)$ \\
\hline \multirow[t]{2}{*}{ proud_cohort } & 0.114 & & -25.52 \\
\hline & $(0.128)$ & & $(41.53)$ \\
\hline \multirow[t]{2}{*}{ joineuro_cohort } & & -0.0362 & \\
\hline & & $(0.0581)$ & \\
\hline Country FE & $\mathrm{x}$ & $\mathrm{x}$ & $\mathrm{x}$ \\
\hline Observations & 15,904 & 15904 & 15904 \\
\hline R-squared & 0.129 & 0.946 & -2.027 \\
\hline
\end{tabular}

Robust standard errors in parentheses

*** $\mathrm{p}<0.01,{ }^{*} * \mathrm{p}<0.05, * \mathrm{p}<0.1$

Test of exclucled instruments:

$F(1,15878)=0.39$

Prob $>F=0.5337$

Endogeneity test of endogenous regressors: 


\section{A.5 Convergence criteria}

Table A.13: Interaction of proud with income

\begin{tabular}{|c|c|c|c|c|c|}
\hline \multirow[b]{3}{*}{ Dependent variable } & \multirow{3}{*}{$\begin{array}{l}\text { OLS } \\
\text { (1) } \\
\text { redistribution }\end{array}$} & \multicolumn{2}{|c|}{ IV - Proud instrumented with joineuro } & \multicolumn{2}{|c|}{ IV - Proud*income instrumented with joineuro*incon } \\
\hline & & (2) & $(3)$ & (4) & (5) \\
\hline & & proud & redistribution & proud_income & redistribution \\
\hline \multirow[t]{2}{*}{ proud } & $-0.362^{* * *}$ & & -163.1 & $4.653^{* * *}$ & $23.19^{* * *}$ \\
\hline & $(0.0654)$ & & $(168.0)$ & $(0.0356)$ & $(7.651)$ \\
\hline \multirow[t]{2}{*}{ proud_income } & $0.0241 *$ & $0.166^{* * *}$ & 27.12 & & $-5.037^{* * *}$ \\
\hline & $(0.0125)$ & $(0.00108)$ & $(27.98)$ & & $(1.643)$ \\
\hline \multirow[t]{2}{*}{ joineuro } & & -0.0120 & & & \\
\hline & & $(0.0124)$ & & & \\
\hline \multirow[t]{2}{*}{ joineuro_income } & & & & $-0.0425^{* * *}$ & \\
\hline & & & & $(0.0132)$ & \\
\hline Country FE & $\mathrm{x}$ & $\mathrm{x}$ & $\mathrm{x}$ & $\mathrm{x}$ & $\mathrm{x}$ \\
\hline Observations & 15,904 & 15,904 & 15,904 & 15,904 & 15,904 \\
\hline R-scyuared & 0.128 & 0.801 & -376.265 & 0.950 & -10.046 \\
\hline \multicolumn{6}{|c|}{ Robust standard errors in parentheses ${ }^{* * *} p<0.01,{ }^{* *} p<0.05,{ }^{*} p<0.1$} \\
\hline \multicolumn{6}{|c|}{ Test of excluded instruments: } \\
\hline & & \multicolumn{2}{|c|}{$F(1,15879)=0.94$} & \multicolumn{2}{|c|}{$\mathrm{F}(1,15879)-10.36$} \\
\hline & & \multicolumn{2}{|c|}{ Prob $>F=0.3329$} & \multicolumn{2}{|c|}{ Prob $>F=0.0013$} \\
\hline \multicolumn{6}{|c|}{ Endogeneity test of endogenous regressors: } \\
\hline & & \multicolumn{2}{|c|}{239.666} & \multicolumn{2}{|c|}{138.805} \\
\hline & & \multicolumn{2}{|c|}{ Chi-sq(1) P-val $=0.0000$} & \multicolumn{2}{|c|}{ Chi-sq(1) P-val $=0.0000$} \\
\hline
\end{tabular}

Table A.14: Additional instruments

\section{PC1 as instrument}

Instrument: duration of first foreign language

1st component of PCA using foreign lang, citizenedu

(5) (6) (7) (8)

\begin{tabular}{|c|c|c|c|c|c|c|c|c|}
\hline & (1) & (2) & (3) & (4) & (5) & $(6)$ & $(7)$ & $(8)$ \\
\hline Dependent variable & $\begin{array}{c}\text { 1st stage } \\
\text { proud }\end{array}$ & $\begin{array}{l}\text { 2nd stage } \\
\text { redistribution }\end{array}$ & $\begin{array}{c}\text { 1st stage } \\
\text { confeu }\end{array}$ & $\begin{array}{l}2 \text { 2nd stage } \\
\text { redistribution }\end{array}$ & $\begin{array}{l}\text { 1st stage } \\
\text { proud }\end{array}$ & $\begin{array}{l}\text { 2nd stiage } \\
\text { redistribution }\end{array}$ & $\begin{array}{l}\text { 1st stage } \\
\text { confeu }\end{array}$ & $\begin{array}{l}\text { 2nd stage } \\
\text { redistributi }\end{array}$ \\
\hline \multirow[t]{2}{*}{ foreign_lang } & -0.00926 & & 0.0154 & & & & & \\
\hline & $(0.00825)$ & & $(0.0101)$ & & & & & \\
\hline \multirow[t]{2}{*}{$p c 1$} & & & & & -0.0172 & & $0.0726^{* * *}$ & \\
\hline & & & & & $(0.0127)$ & & $(0.0156)$ & \\
\hline \multirow[t]{2}{*}{ proud } & & -13.00 & & & & -36.73 & & \\
\hline & & $(11.99)$ & & & & $(27.25)$ & & \\
\hline \multirow[t]{2}{*}{ confeu } & & & & 8.623 & & & & $8.178^{* * *}$ \\
\hline & & & & $(6.218)$ & & & & $(1.950)$ \\
\hline Country FE & $\mathrm{x}$ & x & $\mathrm{x}$ & $\mathrm{x}$ & $\mathrm{x}$ & $\mathrm{x}$ & $\mathrm{x}$ & $\mathrm{x}$ \\
\hline Observations & 15,904 & 15,904 & 14,997 & 14,997 & 11,482 & 11,482 & 11,104 & 11,104 \\
\hline R-squared & 0.116 & -10.137 & 0.044 & -5.868 & 0.103 & -78.986 & 0.041 & -5.160 \\
\hline
\end{tabular}

Robust standard errors in parentheses. ${ }^{* * *} \mathrm{p}<0.01,{ }^{* *} \mathrm{p}<0.05,{ }^{*} \mathrm{p}<0.1$

Test of exchuded instruments:

$\begin{array}{llll}F(1,15880)=1.26 & F(1,14973)=2.31 & F(1,11462)=1.81 & F(1,11084)=21.54 \\ \text { Prob }>F=0.2620 & \text { Prob }>F=0.1283 & \text { Prob }>F=0.1780 & \text { Prob }>F=0.0000 \\ \text { dogenous regressors: } & 15.67 & & 132.181 \\ 12.544 & \text { Chi-sq(1) P-val }=0.0001 & \text { Chi-sq(1) P-val }=0.0000 & \text { Chi-sq(1) P-val }=0.0006 \\ \text { Chi-sq(1) P-val }=0.0004 & \end{array}$


Table A.15: OLS - full sample of countries

\begin{tabular}{|c|c|c|c|c|c|c|c|c|}
\hline & (1) & (2) & (3) & (4) & (5) & $(6)$ & (7) & (8) \\
\hline Dep variable & \multicolumn{8}{|c|}{ redistribution } \\
\hline \multirow[t]{2}{*}{ proud } & $-0.279^{* * *}$ & $-0.205^{* * *}$ & $-0.212^{* * *}$ & $-0.239 * * *$ & & & & \\
\hline & $(0.0179)$ & $(0.0183)$ & $(0.0195)$ & $(0.0216)$ & & & & \\
\hline \multirow[t]{2}{*}{ confeu } & & & & & $-0.253^{* * *}$ & $-0.187^{* * *}$ & $-0.166^{* * *}$ & $-0.142^{* * *}$ \\
\hline & & & & & $(0.0178)$ & $(0.0176)$ & $(0.0191)$ & $(0.0215)$ \\
\hline \multirow[t]{2}{*}{ age } & $0.0206^{* * *}$ & $0.0187^{* * *}$ & $0.0135 * * *$ & $0.0138^{* *}$ & $0.0182^{* * *}$ & $0.0177^{* * *}$ & $0.0126^{* *}$ & $0.0153^{* * *}$ \\
\hline & $(0.00493)$ & $(0.00477)$ & $(0.00518)$ & $(0.00582)$ & $(0.00505)$ & $(0.00487)$ & $(0.00525)$ & $(0.00592)$ \\
\hline \multirow[t]{2}{*}{ age2 } & $-0.000121^{* *}$ & $-0.000132 * * *$ & $-9.12 \mathrm{e}-05^{*}$ & $-8.23 \mathrm{e}-05$ & $-0.000115^{* *}$ & $-0.000142^{* * *}$ & $-9.94 \mathrm{e}-05^{*}$ & $-0.000120^{* *}$ \\
\hline & $(4.90 \mathrm{e}-05)$ & $(4.73 e-05)$ & $(5.13 \mathrm{e}-05)$ & $(5.74 c-05)$ & $(5.05 c-05)$ & $(4.85 e-05)$ & $(5.23 c-05)$ & $(5.86 \mathrm{c}-05)$ \\
\hline \multirow[t]{2}{*}{ female } & $0.157^{* * *}$ & $0.149^{* * *}$ & $0.146^{* * *}$ & $0.127^{* * *}$ & $0.162^{* * *}$ & $0.138^{* * *}$ & $0.138^{* * *}$ & $0.121^{* * *}$ \\
\hline & $(0.0274)$ & $(0.0264)$ & $(0.0284)$ & $(0.0319)$ & $(0.0277)$ & $(0.0266)$ & $(0.0286)$ & $(0.0322)$ \\
\hline secondary & $-0.676^{* * *}$ & $-0.507^{* * *}$ & $-0.479^{* * *}$ & $-0.526^{* * *}$ & $-0.639^{* * * *}$ & $-0.446^{* * *}$ & $-0.404^{* * *}$ & $-0.458^{* * *}$ \\
\hline _incomplete & $(0.0471)$ & $(0.0482)$ & $(0.0527)$ & $(0.0608)$ & $(0.0483)$ & $(0.0492)$ & $(0.0536)$ & $(0.0622)$ \\
\hline \multirow[t]{2}{*}{ secondary } & $-0.382^{* * *}$ & $-0.573^{* * *}$ & $-0.459^{* * *}$ & $-0.466^{* * *}$ & $-0.335^{* * *}$ & $-0.512^{* * *}$ & $-0.391^{* * *}$ & $-0.403^{* * *}$ \\
\hline & $(0.0377)$ & $(0.0383)$ & $(0.0422)$ & $(0.0489)$ & $(0.0384)$ & $(0.0390)$ & $(0.0428)$ & $(0.0497)$ \\
\hline \multirow[t]{2}{*}{ tertiary } & $-0.989 * * *$ & $-1.102^{* * *}$ & $-0.828^{* * *}$ & $-0.836^{* * *}$ & $-0.858 * * *$ & $-0.961 * * *$ & $-0.704^{* * *}$ & $-0.726^{* * *}$ \\
\hline & $(0.0403)$ & $(0.0410)$ & $(0.0464)$ & $(0.0541)$ & $(0.0408)$ & $(0.0415)$ & $(0.0465)$ & $(0.0543)$ \\
\hline \multirow[t]{2}{*}{ married } & $-0.306^{* * *}$ & $-0.171^{* * *}$ & -0.0437 & -0.00726 & $-0.323^{* * *}$ & $-0.187^{* * *}$ & $-0.0752^{* * *}$ & -0.0443 \\
\hline & $(0.0324)$ & $(0.0317)$ & $(0.0342)$ & $(0.0386)$ & $(0.0328)$ & $(0.0320)$ & $(0.0345)$ & $(0.0389)$ \\
\hline \multirow[t]{2}{*}{ Dchildren } & -0.0531 & $-0.0845^{* *}$ & $-0.0974^{* *}$ & $-0.128^{* * * *}$ & -0.0421 & $-0.0751^{* *}$ & $-0.0724 *$ & $-0.0951 * *$ \\
\hline & $(0.0389)$ & $(0.0380)$ & $(0.0404)$ & $(0.0461)$ & $(0.0391)$ & $(0.0380)$ & $(0.0403)$ & $(0.0460)$ \\
\hline \multirow[t]{2}{*}{ income } & & & $-0.134^{* * *}$ & $-0.127^{* * *}$ & & & $-0.126 * * *$ & $-0.123^{* * *}$ \\
\hline & & & $(0.00718)$ & $(0.00809)$ & & & $(0.00726)$ & $(0.00821)$ \\
\hline \multirow[t]{2}{*}{ unemployed } & & & $0.191^{* * *}$ & $0.162^{* *}$ & & & $0.216^{* * *}$ & $0.197^{* * *}$ \\
\hline & & & $(0.0553)$ & $(0.0638)$ & & & $(0.0555)$ & $(0.0641)$ \\
\hline \multirow[t]{2}{*}{ townsize } & & & & $-0.0222 * * *$ & & & & -0.00833 \\
\hline & & & & $(0.00712)$ & & & & $(0.00720)$ \\
\hline \multirow[t]{2}{*}{ wave } & & $-1.212^{* * *}$ & $-0.875 * * *$ & $-0.428^{* *}$ & & $-1.126^{* * *}$ & $-0.798^{* * *}$ & $-0.329^{*}$ \\
\hline & & $(0.138)$ & $(0.150)$ & $(0.179)$ & & $(0.139)$ & $(0.151)$ & $(0.181)$ \\
\hline \multirow[t]{2}{*}{ wave 2} & & $0.162^{* * *}$ & $0.131^{* * *}$ & $0.0895 * * *$ & & $0.157^{* * *}$ & $0.126^{* * *}$ & $0.0809^{* * *}$ \\
\hline & & $(0.0156)$ & $(0.0167)$ & $(0.0198)$ & & $(0.0157)$ & $(0.0168)$ & $(0.0200)$ \\
\hline \multirow[t]{2}{*}{ Constant } & $6.676^{* * *}$ & $8.216^{* * *}$ & $7.989^{* * *}$ & $7.041^{* * *}$ & $6.419^{* * *}$ & $7.741^{* * *}$ & $7.385^{* * *}$ & $6.170^{* * *}$ \\
\hline & $(0.124)$ & $(0.317)$ & $(0.349)$ & $(0.416)$ & $(0.119)$ & $(0.321)$ & $(0.352)$ & $(0.423)$ \\
\hline Country FE & & $\mathrm{x}$ & $\mathrm{x}$ & $\mathrm{x}$ & & $\mathrm{x}$ & $\mathrm{x}$ & $\mathrm{x}$ \\
\hline Observations & 40,178 & 40,178 & 34,069 & 27,876 & 39,008 & 39,008 & 33,401 & 27,132 \\
\hline R-squared & 0.028 & 0.101 & 0.109 & 0.117 & 0.026 & 0.103 & 0.110 & 0.120 \\
\hline \multicolumn{4}{|c|}{ Robust standard errors in parentheses } & $* * * p<0.01$ & ${ }^{*} \mathrm{p}<0.05, *$ & 0.1 & & \\
\hline
\end{tabular}


Table A.16: IV - full sample of countries

\begin{tabular}{|c|c|c|c|c|}
\hline Dependent variable & $\begin{array}{l}(1) \\
\text { 1st stage } \\
\text { proud }\end{array}$ & $\begin{array}{l}(2) \\
2 \text { nd stage } \\
\text { redistribution }\end{array}$ & $\begin{array}{l}(3) \\
\text { 1st stage } \\
\text { confeu }\end{array}$ & $\begin{array}{l}(4) \\
\text { 2nd stage } \\
\text { redistribution }\end{array}$ \\
\hline joincuro & $\begin{array}{l}0.0336^{*} \\
(0.0195)\end{array}$ & & $\begin{array}{l}0.0728^{* * *} \\
(0.0223)\end{array}$ & \\
\hline proud & & $\begin{array}{l}19.81^{*} \\
(11.77)\end{array}$ & & \\
\hline confeu & & & & $\begin{array}{l}8.616^{* * *} \\
(2.896)\end{array}$ \\
\hline age & $\begin{array}{l}-0.00371^{* *} \\
(0.00168)\end{array}$ & $\begin{array}{l}0.0885 \\
(0.0557)\end{array}$ & $\begin{array}{l}-0.0181^{* * *} \\
(0.00180)\end{array}$ & $\begin{array}{l}0.174^{* * *} \\
(0.0552)\end{array}$ \\
\hline age 2 & $\begin{array}{l}8.67 \mathrm{e}-05^{* * *} \\
(1.63 \mathrm{e}-05)\end{array}$ & $\begin{array}{l}-0.00182^{*} \\
(0.00108)\end{array}$ & $\begin{array}{l}0.000173^{* * *} \\
(1.77 \mathrm{e}-05)\end{array}$ & $\begin{array}{l}-0.00163^{* * *} \\
(0.000529)\end{array}$ \\
\hline female & $\begin{array}{l}0.0151^{*} \\
(0.00910)\end{array}$ & $\begin{array}{l}-0.172 \\
(0.255)\end{array}$ & $\begin{array}{l}0.00840 \\
(0.00970)\end{array}$ & $\begin{array}{l}0.0495 \\
(0.0939)\end{array}$ \\
\hline secondary_incomplete & $\begin{array}{l}-0.0839^{* * *} \\
(0.0162)\end{array}$ & $\begin{array}{l}1.169 \\
(1.046)\end{array}$ & $\begin{array}{l}0.0215 \\
(0.0184)\end{array}$ & $\begin{array}{l}-0.634^{* * *} \\
(0.181)\end{array}$ \\
\hline secondary & $\begin{array}{l}-0.103^{* * *} \\
(0.0135)\end{array}$ & $\begin{array}{l}1.601 \\
(1.244)\end{array}$ & $\begin{array}{l}0.0112 \\
(0.0150)\end{array}$ & $\begin{array}{l}-0.502^{* * *} \\
(0.144)\end{array}$ \\
\hline tertiary & $\begin{array}{l}-0.204^{* * *} \\
(0.0156)\end{array}$ & $\begin{array}{l}3.271 \\
(2.434)\end{array}$ & $\begin{array}{l}0.102^{* * *} \\
(0.0166)\end{array}$ & $\begin{array}{l}-1.611^{* * *} \\
(0.329)\end{array}$ \\
\hline married & $\begin{array}{l}0.0541 * * * \\
(0.0112)\end{array}$ & $\begin{array}{l}-1.099 \\
(0.676)\end{array}$ & $\begin{array}{l}0.0195^{*} \\
(0.0118)\end{array}$ & $\begin{array}{l}-0.222^{*} \\
(0.125)\end{array}$ \\
\hline Dchildren & $\begin{array}{l}-0.0104 \\
(0.0138)\end{array}$ & $\begin{array}{l}0.0887 \\
(0.306)\end{array}$ & $\begin{array}{l}0.00594 \\
(0.0142)\end{array}$ & $\begin{array}{l}-0.138 \\
(0.134)\end{array}$ \\
\hline income & $\begin{array}{l}0.00905^{* * *} \\
(0.00229)\end{array}$ & $\begin{array}{l}-0.302^{* * *} \\
(0.114)\end{array}$ & $\begin{array}{l}0.0293^{* * *} \\
(0.00242)\end{array}$ & $\begin{array}{l}-0.373^{* * *} \\
(0.0866)\end{array}$ \\
\hline unemployed & $\begin{array}{l}-0.0891^{* * *} \\
(0.0191)\end{array}$ & $\begin{array}{l}1.956^{*} \\
(1.124)\end{array}$ & $\begin{array}{l}-0.0511^{* * *} \\
(0.0195)\end{array}$ & $\begin{array}{l}0.652^{* * *} \\
(0.237)\end{array}$ \\
\hline townsize & $\begin{array}{l}-0.0159^{* * *} \\
(0.00204)\end{array}$ & $\begin{array}{l}0.296 \\
(0.191)\end{array}$ & $\begin{array}{l}0.0180^{* * *} \\
(0.00217)\end{array}$ & $\begin{array}{l}-0.167^{* * *} \\
(0.0564)\end{array}$ \\
\hline wave & $\begin{array}{l}-0.103^{* *} \\
(0.0503)\end{array}$ & $\begin{array}{l}1.506 \\
(1.543)\end{array}$ & $\begin{array}{l}0.00734 \\
(0.0550)\end{array}$ & $\begin{array}{l}-0.547 \\
(0.521)\end{array}$ \\
\hline wave 2 & $\begin{array}{l}0.0143^{* * *} \\
(0.00548)\end{array}$ & $\begin{array}{l}-0.201 \\
(0.206)\end{array}$ & $\begin{array}{l}-0.00193 \\
(0.00595)\end{array}$ & $\begin{array}{l}0.0973^{*} \\
(0.0566)\end{array}$ \\
\hline Constant & $\begin{array}{l}3.497^{* * *} \\
(0.116)\end{array}$ & $\begin{array}{l}-62.55 \\
(41.00)\end{array}$ & $\begin{array}{l}2.911^{* * *} \\
(0.130)\end{array}$ & $\begin{array}{l}-18.72^{* *} \\
(8.201)\end{array}$ \\
\hline Country FE & $\mathrm{x}$ & $\mathrm{x}$ & $\mathrm{x}$ & $\mathrm{x}$ \\
\hline Observations & 27,876 & 27,876 & 27,132 & 27,132 \\
\hline R-squared & 0.130 & -28.348 & 0.071 & -5.967 \\
\hline
\end{tabular}

Robust standard errors in parentheses. ${ }^{* * *} \mathrm{p}<0.01,{ }^{* *} \mathrm{p}<0.05,{ }^{*} \mathrm{p}<0.1$

Test of excluded instruments:

$$
\begin{array}{ll}
F(1,27845)=2.96 & F(1,27101)=10.69 \\
\text { Prob }>F=0.0853 & \text { Prob }>F=0.0011
\end{array}
$$

Endogeneity test of endogenous regressors:

$$
\begin{array}{ll}
85.196 & 74.284 \\
\text { Chi-sq(1) P-val }=0.4000 & \text { Chi-sq(1) P-val }=0.0000
\end{array}
$$


Table A.17: Correlation coefficients between redistribution and convergence criteria

\begin{tabular}{rc}
\hline & Redistribution \\
\hline Inflation & -0.1117 \\
Interest & 0.0297 \\
Debt & 0.0136 \\
Balance of payments & 0.1138
\end{tabular}

Note: Table shows the correlation between redistribution and convergence criteria in the respective year and country for those countries that joined the European Union after 2003. See next table for definitions and data on convergence criteria.

Table A.18: Convergence criteria: data and definitions

\begin{tabular}{|c|c|c|c|c|c|}
\hline & & Inflation rate & Long-term interest rate & Government debt & Balance of payments \\
\hline Bulgaria & 1997 & & & 97.3 & 5.4 \\
\hline Bulgaria & 2005 & 6 & 3.87 & 27.1 & -11.6 \\
\hline Croatia & 1996 & & & & \\
\hline Cyprus & 2006 & 2.2 & 4.13 & 59.3 & -7 \\
\hline Cyprus & 2011 & 3.5 & 5.79 & 66 & -3.4 \\
\hline Czech Republic & 1991 & & & & \\
\hline Estonia & 1996 & & & & -8.4 \\
\hline Estonia & 2011 & 5.1 & & 6 & 1.8 \\
\hline Hungary & 1982 & & & & \\
\hline Hungary & 1998 & 14.2 & & 60.1 & -4.8 \\
\hline Hungary & 2009 & 4 & 9.12 & 78.2 & -0.2 \\
\hline Latvia & 1996 & & & 13.3 & -5 \\
\hline Lithuania & 1997 & 10.3 & & & -9.7 \\
\hline Poland & 1989 & & & & \\
\hline Poland & 1997 & 15 & & 42.3 & -3.7 \\
\hline Poland & 2005 & 2.2 & 5.22 & 46.7 & -2.4 \\
\hline Poland & 2012 & 3.7 & 5 & 54.4 & -3.7 \\
\hline Romania & 1998 & 59.1 & & 16.7 & -7 \\
\hline Romania & 2005 & 9.1 & & 15.7 & -8.6 \\
\hline Romania & 2012 & 3.4 & 6.68 & 37.3 & -4.4 \\
\hline Slovakia & 1990 & & & & \\
\hline Slovakia & 1998 & 6.7 & & 33.9 & -9.5 \\
\hline Slovenia & 1995 & & & 18.3 & -0.3 \\
\hline Slovenia & 2005 & 2.5 & 3.81 & 26.3 & -1.7 \\
\hline Slovenia & 2011 & 2.1 & 4.97 & 46.5 & 0.4 \\
\hline
\end{tabular}

Note: Table shows data on convergence criteria from the Eurostata database. Definitions:

- Inflation rate: HICP $(2005=100)$ - annual data (average index and rate of change).

- Long-term interest rate: EMU convergence criterion bond yields.

- Government debt: General government consolidated gross debt, percentage of GDP.

- Balance of payments: Main balance of payments as share of GDP (current account, partner all countries of the world).

Data sources:

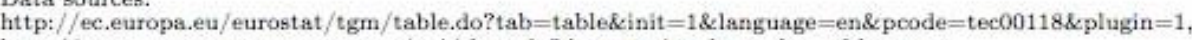

http://appsso.eurostat.ec.europa.eu/nui/show.do?dataset =irt_lt_mcby_a\&lang=en,

http://appsso.eurostat.ec.europa.eu/nui/submitVlewTableAction.do 